NBER WORKING PAPER SERIES

\title{
EXCHANGE RATE CHANGES AND INFLATION IN POST-CRISIS ASIAN ECONOMIES: VAR ANALYSIS OF THE EXCHANGE RATE PASS-THROUGH
}

\author{
Takatoshi Ito \\ Kiyotaka Sato \\ Working Paper 12395 \\ http://www.nber.org/papers/w12395
NATIONAL BUREAU OF ECONOMIC RESEARCH
1050 Massachusetts Avenue
Cambridge, MA 02138
July 2006

The authors are grateful to Professors Eiji Ogawa, Etsuro Shioji, Yuri N. Sasaki, Kentaro Kawasaki, Willem Thorbecke, Drs. Masaru Yoshitomi, Junko Shimizu and Yelena F. Takhtamanova for their insightful comments. Research support by JSPS Grant-in-Aid for Scientific Research, (A-2), No. 15203008, to the first author and by MEXT Grant-in-Aid for Young Scientists (B), No. 16730145, to the second author are gratefully acknowledged. The views expressed herein are those of the author(s) and do not necessarily reflect the views of the National Bureau of Economic Research.

(C2006 by Takatoshi Ito and Kiyotaka Sato. All rights reserved. Short sections of text, not to exceed two paragraphs, may be quoted without explicit permission provided that full credit, including $\odot$ notice, is given to the source. 
Exchange Rate Changes and Inflation in Post-Crisis Asian Economies: VAR Analysis of the

Exchange Rate Pass-Through

Takatoshi Ito and Kiyotaka Sato

NBER Working Paper No. 12395

July 2006

JEL No. F12, F31, F41

\begin{abstract}
$\underline{\text { ABSTRACT }}$
Macroeconomic consequences of a large currency depreciation among the crisis-hit Asian economies had varied from one country to another. Inflation did not soar in most Asian countries, including Thailand and Korea, after the exchange rate depreciated during the crisis. Indonesia, however, suffered very high inflation following a very large nominal depreciation of the rupiah. As a result, price competitive advantage by the rupiah depreciation was lost in the real exchange rate terms. The objective of this paper is to examine the pass-through effects of exchange rate changes on the domestic prices in the East Asian economies using a VAR analysis. Main results are as follows: (1) the degree of exchange rate pass-through to import prices was quite high in the crisis-hit economies; (2) the pass-through to CPI was generally low, with a notable exception of Indonesia: and (3) in Indonesia, both the impulse response of monetary policy variables to exchange rate shocks and that of CPI to monetary policy shocks are positive, large, and statistically significant. Thus, Indonesia's accommodative monetary policy, coupled with the high degree of the CPI responsiveness to exchange rate changes was an important factor in the spiraling effects of domestic price inflation and sharp nominal exchange rate depreciation in the post-crisis period.
\end{abstract}

Takatoshi Ito

Graduate School of Economics

University of Tokyo

7-2-1 Hongo, Bunkyo-ku

Tokyo, 113-0033

JAPAN

and NBER

tito@e.u-tokyo@ac.jp

Kiyotaka Sato

Faculty of Economics

Yokohama National University

79-3 Tokiwadai, Hodogaya

Yokohama 240-8501

JAPAN

sato@ynu.ac.jp 


\section{Introduction}

The objective of this paper is to examine pass-through effects of the exchange rate changes on the domestic prices among the East Asian countries. In order to take into account of bi-directional effects, as well as other macroeconomic factors, between domestic inflation and exchange rate changes, a vector autoregression (VAR) analysis with five or seven variables, is used. The crisis-affected Asian countries have experienced varying degree of exchange rate and inflation rate changes following an initial shock of sharp depreciation of their currencies in the fall of 1997 . In some countries, such as Korea, a sharp nominal depreciation was followed by a sharp reversal within several months, with little effects on domestic inflation. In some other countries, such as Indonesia, a very large depreciation resulted in high inflation, so that the real exchange rate did not change much to promote exports.

Whether the exchange rate changes have significant impact on the domestic prices has several important implications to thinking of the role of the exchange rate in macroeconomic policy design. It is commonly thought that if the degree of pass-through is high, the exchange rate changes will change the relative prices of tradables and non-tradables, so that the adjustment in trade balances will be relatively prompt. For example, imported goods become expensive, if pass-through is high, so that expenditure switching from imports to domestic goods will occur and external balances will be corrected in several months. On the other hand, if the degree of pass-through is low, the exchange rate does not have much impact on the trade balance.

Another important aspect is the interaction between the exchange rate and domestic prices including both tradables and non-tradables. Suppose that a country is experiencing trade deficits and the exchange rate depreciates, then export competitiveness is strengthened, resulting in improvement in external balances. 
However, if domestic prices in general respond to the nominal exchange rate depreciation one-to-one-that is, pass-through not only to import prices but to CPI in general-then any export competitiveness from nominal depreciation would be cancelled out. A combination of nominal depreciation and high inflation leaves the export competitiveness unchanged, while corporations and financial institutions that had net foreign-currency liabilities become burdened by larger real debts and nonperforming loans.

Hence, from the viewpoint of using the exchange rate changes as an instrument for correcting (reducing deficits and possibly making surpluses in) the trade balance, the pass-through to import prices and possibly wholesale prices to force expenditure switching is good, but the pass-through to CPI, raising all price levels, is bad. Monetary policy should be operated with knowledge of this distinction.

Post-crisis Asian countries provide a rich "natural” experiment of large exchange rate changes and different domestic responses. In order to examine what exactly happened in the post-crisis Asian economies in terms of pass-through at different levels, we need to build a framework that includes different kinds of price indices as well as the nominal exchange rate. The pass-through question is to examine the direction from the exchange rate to domestic prices. There is a large literature of pass-through effects, with a single-equation regression explaining responses of a domestic price index from the changes in the exchange rate. See, for example, Feenstra (1989), Olivei (2002), Campa and Goldberg (2005), Campa, Goldberg and Gonzáles-Mínguez (2005), Otani, Shiratsuka and Shirota (2005). However, a single-equation pass-through regression ignores the fact that domestic inflation may affect the exchange rate. In order to examine a reinforcing mechanism between domestic prices and the exchange rate, a VAR analysis is necessary. Recent 
studies, such as McCarthy (2000), Hahn (2003) and Faruqee (2004), use a VAR approach for an analysis of pass-through of several types of shocks to domestic inflation. However, these studies examine the pass-through in advanced countries and the data covers the relatively peace (non-crisis) time which contrasts sharply with the crisis period experienced by East Asian economies.

The novelty of this paper is three-fold: First, by focusing on the interaction between the exchange rate and inflation, new insights on the difficulty of Indonesia in the post-crisis period will be examined. Most of existing studies examine the nominal exchange rate to describe the recovery and non-recovery process; Second, a VAR analysis, which allows the reverse causality from inflation to the exchange rate, is applied to crisis-affected countries; and third, to use several domestic price indices so that we may examine how pass-through effects may be watered down as weights of domestic (nontradable) value added increase, from import prices to wholesale prices, to consumer price indices.

The rest of this paper is organized as follows. Section 2 describes the brief history of currency movements of the Asian currency crisis. Section 3 discusses the analytical framework of this paper. The results of a VAR analysis are presented in Section 4. Section 5 checks the robustness of the empirical findings. Section 6 concludes.

\section{Experiences of the Asian Countries}

In the episode of the Asian currency crisis, the interaction of the exchange rate and domestic prices varied from one country to another. After the floatation of the Thai baht on July 2, 1997, some Asian currencies immediately depreciated (vis-à-vis the US dollar), while others held on to a de facto dollar peg for several months before 
experiencing a large depreciation. Although the Asian currency crisis is commonly considered to be a case of rapid contagion across Asia from Thailand to Indonesia, to Korea, the process took more than several months before the full crisis developed in December 1997. In some interpretation, the Asian currency crisis was not due to a single shock to Thailand but multiple shocks to Thailand, Indonesia, and Korea with reinforcing spillover to each other. ${ }^{3}$ Reasons for the downfall of the currencies seemed to be different in different countries.

Since reasons for a crisis were different in several countries, it is natural that recovery processes were also different. It is well recognized that the crisis was most severe and the recovery took much longer in Indonesia than others. By several measures, Indonesia suffered most damages in the financial crisis of 1997-98. The Indonesian rupiah depreciated to one-sixth of the pre-crisis level in the mid-January 1998, about 16,000 rupiah/dollar. The rupiah recovered somewhat in the spring, but again went to the 15,000 in May 1998, when the political crisis reached a climax, that resulted in the resignation of President Suharto. Capital outflows continued, and the recovery of nominal exchange rate from that trough was very much delayed.

The value of Asian currencies other than the Indonesian rupiah recovered from January to mid-1998, and then they were stabilized at around 60 to $70 \%$ of the pre-crisis level by the mid-1998. The recovery of the Indonesian rupiah was much slower and never recovered to the level (relative to the pre-crisis level) of other Asian currencies. Figure 1 shows the development of the Asian exchange rates.

*** Insert Figure 1. ***

\footnotetext{
${ }^{3}$ See Ito and Hashimoto (2002) for high-frequency contagion of the exchange rate changes among the Asian currencies during the Asian currency crisis.
} 
It was not only the exchange rate but the inflation rate in Indonesia that was different from other countries. The inflation rate of Indonesia became very high for any country in 1998 and 1999 and remained higher than most Asian countries in the period from 2000 to 2003 (Figure 2). Although the Indonesian exchange rate depreciated much more than other countries, inflation cancelled out some of price competitiveness that came from depreciation. By 2004, the real exchange rate of Indonesia became similar to that of Thailand, the Philippines, and Malaysia. The export advantage of Indonesia was completely offset by 2004 (Figure 3).

\section{*** Insert Figures 2 and 3. ***}

So far, the story is told in terms of the bilateral nominal and real exchange rate vis-à-vis the US dollar. However, export competitiveness of a county is most accurately measured by the real effective exchange rate (the multilateral version of the real exchange rate). The trade weights can be used for defining multilateral effective exchange rate. ${ }^{4}$ The pass-through should be defined as the exchange rate changes of trading partners and the impact should be measured as the weighted average of those exchange rates.

\section{Analytical Framework}

The exchange rate is determined by, among others, the interest rate, inflation rate, and other macroeconomic variables that are subject to monetary and fiscal

\footnotetext{
${ }^{4}$ To be precise, price elasticities should be taken into account. See Ito, Ogawa, and Sasaki (1998).
} 
policies. It is theoretically well-known and empirically verifiable in the low frequency data that high inflation rate (vis-à-vis the trading partner countries) will surely cause depreciation of the currency and that the low interest rate tends to do the same. However, many relatively high-frequency empirical studies have found that the exchange rate is unpredictable and statistically exogenous to (Granger-cause) many macroeconomic variables. The changes in the exchange rate tend to affect pricing behaviors of the firms and to influence macroeconomic policies. Therefore, ideally, any analysis of interaction between the exchange rate and domestic inflation should allow a bi-directional causal relationship: from the exchange rate to domestic variables and from domestic variables to the exchange rate. The effect of the exchange rate changes on domestic price variables is called pass-through, while the reverse effect is the determination of the exchange rate in an open macroeconomics.

In the fixed exchange rate regime, policies are assigned to keep the exchange rate at the committed exchange rate. Capital flows resulting from macroeconomic shocks and investors' assessment of the country as a destination of portfolio investment have to be countered by policies, so that the interest rate and the inflation rate may fluctuate, but the exchange rate. In the floating exchange rate regime, the exchange rate is one of the endogenous variables that respond to economic policies. Since the exchange rate and the inflation rate are expected to be influencing each other in many theoretical models, it is most appropriate to estimate a system that would treat both of them endogenous. In particular, during the currency crisis period, a large swing of exchange rate is likely to affect domestic macroeconomic variables. A VAR is a useful approach to allow for such interaction between exchange rate and domestic variables.

A VAR analysis of the exchange rate pass-through has the following 
advantages over a single-equation version of pass-through analysis. First, a VAR technique enables us to identify structural shocks through a Cholesky decomposition of innovations. Effects of structural shocks to other macroeconomic variables on domestic inflation are also investigated under a VAR framework. Second, previous studies typically analyze the exchange rate pass-through into a single price index by employing a single-equation-based approach. ${ }^{5}$ A VAR approach, in contrast, allows us to investigate the exchange rate pass-through into a set of domestic prices along the pricing chain from the import/producer level to the consumer level.

This paper analyzes the pass-through effect of the exchange rate on domestic inflation in the following way. First, we employ a 5-variable VAR including the exchange rate, the consumer price index (CPI) and other macroeconomic variables. Structural shocks to the exchange rate and other variables are identified through a Cholesky decomposition of innovations. It is investigated how domestic macroeconomic variables respond to exchange rate shocks through the impulse response function analysis. Second, in addition to CPI, we try other domestic price variables, i.e., producer price index (PPI) and import price index (or import unit values, to be abbreviated as IMP). We include each price variable one by one and compare estimated results between the three price variables. We expect that the degree of pass-through to IMP would be larger than that of PPI and CPI, because non-tradable goods are included in CPI and distribution costs along the pricing chain may cause a

\footnotetext{
${ }^{5}$ The seminal work on the exchange rate pass-through is, inter alia, Knetter $(1989,1993)$ and Feenstra (1989). Although there have been a large number of studies focusing on exchange rate pass-through of Japanese trade such as Ohno (1989), Marston (1990) and Otani, Shiratsuka and Shirota (2005), only a few attempts have been made at the exchange rate pass-through of East Asian trade. See, for instance, Toh and Ho (2001), Sasaki (2005), and Parsons and Sato (2006).
} 
decline in the degree of pass-through from upstream to downstream prices. ${ }^{6}$ We also include all three price variables together in a 7-variable VAR and examine the pass-through effects of exchange rate shocks on a set of prices along the pricing chain. Third, in addition to the analysis for the whole sample period, we conduct estimation for the sub-sample period ranging from July 1997 to the present, as several countries started to change their exchange rate regime from the de facto US dollar peg into more flexible exchange rate system once hit by the crisis. This additional analysis with the sub-sample reveals how the pass-through effect has changed after shifting to a post-crisis exchange rate regime.

We set up the following VAR model (baseline model) with the vector of five endogenous variables, $x_{t}=\left(\Delta \text { oil }_{t}, g p_{t}, \Delta m_{t}, \Delta e f e x r_{t}, \Delta p_{t}\right)^{\prime}$, where oil $t_{t}$ denotes the natural $\log$ of oil prices; gap $p_{t}$ the output gap; $m_{t}$ the natural log of money supply (base money or M1); efexr $r_{t}$ that of nominal effective exchange rate; and $p_{t}$ that of domestic prices. $\Delta$ represents the first difference operator. As will be discussed below, we take the first-difference of all variables except for $g a p_{t}$ to ensure the stationarity of variables. Previous studies, such as McCarthy (2000) and Hahn (2003), use a 7- or 8-variable VAR. Our baseline model includes just five variables, primarily in consideration of the relatively small sample size. In the later section, we also attempt to extend the baseline model to a 7-variable VAR including all three price variables to check the robustness and to investigate directly the pass-through effect across the prices.

Variables for our baseline model are selected with the following research intent and empirical consideration. First, we include the oil price and the output gap

\footnotetext{
${ }^{6}$ Goldberg and Campa (2006) have empirically shown that distribution margins as well as the higher share of imported inputs reduce the extent of transmission of exchange rate changes to consumer prices.
} 
in a VAR model following McCarthy (2000) and Hahn (2003). Supply shocks are identified by the oil price inflation. The US dollar denominated oil price is used for our analysis so that we can investigate the effect of oil price changes themselves, and not the effect of large changes in the bilateral exchange rate vis-à-vis the US dollar. ${ }^{7}$ To capture the demand side effect, we include the output gap which is constructed by applying the Hodrick-Prescott (HP) filter to industrial production index. ${ }^{8}$

Second, the base money is used to allow for the effects of monetary policy on inflation. McLeod (2003) argues that Indonesia's high inflation after the currency crisis is primarily caused by the increase in base money that reflects the monetary policy of the Bank Indonesia (the central bank of Indonesia). The VAR approach enables us to identify monetary policy shocks controlling for other factors. ${ }^{9}$ If indeed the monetary factor was dominant, then we will confidently determine the source of inflation as a mistake of the monetary policy.

Third, the nominal effective exchange rate is used in our VAR. Although many studies have used the bilateral exchange rate vis-à-vis the US dollar, the effective exchange rate is the right concept when the total effect of the exchange rate changes is what we would like to measure. If a country has higher trade dependence on neighboring countries that experience the same degree of currency depreciations, then the country may not gain any price competitiveness of their exports or they will not

\footnotetext{
${ }^{7}$ The fluctuation of local currency oil prices for East Asian countries from the mid-1990s largely reflect the changes in bilateral exchange rate vis-à-vis the US dollar rather than the oil price fluctuations per se.

${ }^{8}$ We follow Hahn (2003) and the cyclical components generated by applying the HP filter to industrial production index are used as the output gap.

${ }^{9}$ Recently, several studies such as Azis and Thorbecke (2004) and Caporale, Cipollini and Demetriades (2005) use a VAR technique to examine the interaction between monetary policy and exchange rate changes during and after the Asian currency crisis. However, such studies do not allow for the exchange rate pass-through in the analysis.
} 
experience much inflationary pressure from imports, since the effective exchange rate would not change much. In addition, although most East Asian countries had adopted a de facto US dollar peg at least up to the currency crisis of 1997, the bilateral rate vis-à-vis the US dollar is an inappropriate variable to use for this study. We also conduct estimation for a sub-sample starting from the crisis period, as several countries started to change the de facto US dollar peg into more flexible exchange rate system once hit by the crisis. The estimation for the sub-sample enables us to investigate whether such changes in exchange rate policy affected the pass-through effect in the countries concerned.

Fourth, the consumer price index (CPI) is included in the baseline model as a measure of domestic inflation. The CPI includes both imported and, more generally, tradable goods and non-tradable goods and services. In order to extract the impact of the currency depreciation on prices, it may be better to examine responsiveness of tradable prices separately. Therefore models with other types of prices, i.e., the producer price index (PPI) or the import price index (IMP), will be examined. Similar analyses were conducted by McCarthy (2000), Hahn (2003) and Faruqee (2004). To investigate the difference in response to shocks among those different price measures, 5-variable VAR models are estimated with different price measures; i.e., each has one price variable in the VAR system, and then the price responses to the currency shock will be prepared. In addition, a 7-variable VAR including three measures of price variables, CPI, PPI and IMP, in one system will be estimated to directly analyze the effects of shocks on prices at different stages of the pricing chain from imports to retails.

The primary objective of this paper is to estimate impacts of exchange rate changes and other types of shocks on domestic price inflation. To recover these 
structural shocks, a Choleski decomposition of the matrix $\Omega$, a variance-covariance matrix of the reduced-form VAR residuals $\left(u_{t}\right)$, is used to generate structural disturbances $\left(\varepsilon_{t}\right)$. The relationship between the reduced-form VAR residuals and the structural disturbances can be written as follows: ${ }^{10}$

$$
\left(\begin{array}{l}
u_{t}^{\text {oil }} \\
u_{t}^{\text {gap }} \\
u_{t}^{m} \\
u_{t}^{\text {efexr }} \\
u_{t}^{p}
\end{array}\right)=\left(\begin{array}{ccccc}
S_{11} & 0 & 0 & 0 & 0 \\
S_{21} & S_{22} & 0 & 0 & 0 \\
S_{31} & S_{32} & S_{33} & 0 & 0 \\
S_{41} & S_{42} & S_{43} & S_{44} & 0 \\
S_{51} & S_{52} & S_{53} & S_{54} & S_{55}
\end{array}\right)\left(\begin{array}{l}
\varepsilon_{t}^{\text {oil }} \\
\varepsilon_{t}^{\text {gap }} \\
\varepsilon_{t}^{m} \\
\varepsilon_{t}^{\text {efexr }} \\
\varepsilon_{t}^{p}
\end{array}\right) .
$$

The structural model is identified because the $k(k-1) / 2$ restrictions are imposed on the matrix $S$ as zero restrictions where $k$ denotes the number of endogenous variables. The resulting lower-triangular matrix $S$ implies that some structural shocks have no contemporaneous effect on some endogenous variables given the ordering of endogenous variables.

Determining the most reasonable order of the endogenous variables is particularly important to identify structural shocks. The change in oil prices is ordered first because the reduced-form residuals of oil prices are unlikely affected contemporaneously by any other shocks except oil price (supply) shocks per se, while oil price shocks likely affect all variables in the system contemporaneously.

\footnotetext{
${ }^{10}$ A unique lower-triangular matrix $S$ can be derived given the positive definite symmetric matrix $\Omega$. That is, the Choleski decomposition of $\Omega$ implies $\Omega=P P^{\prime}$ where the Choleski factor, $P$, is a lower-triangular matrix. Since $\Omega=E\left(u_{t} u_{t}^{\prime}\right)=S E\left(\varepsilon_{t} \varepsilon_{t}^{\prime}\right) S^{\prime}=S S^{\prime}$ where structural disturbances are assumed to be orthonormal, i.e., $E\left(\varepsilon_{t} \varepsilon_{t}^{\prime}\right)=I$, the lower-triangular matrix $S$ is equal to the Choleski factor $P$.
} 
Indonesia is not influential oil-producer in the global oil market. The output gap is placed second in the ordering as the output gap can be considered to be contemporaneously affected by only oil price shocks while output gap (demand) shocks have a contemporaneous impact on other variables except oil prices. The base money is ordered third because it is included as a representative of monetary policy and, hence, it seems more reasonable to assume that monetary policy shocks have a contemporaneous effect on the exchange rate than vice versa. Basically, the monetary policy reaction function is assumed to responds to the current oil prices (supply shock) and the GDP gap (both supply and demand shocks), and the effect of the monetary policy shocks affect prices and the exchange rate immediately. To put differently, the reduced-form residuals of the base money is assumed not to react contemporaneously to price shocks, while monetary policy shocks affect the domestic price inflation contemporaneously. ${ }^{11}$ The nominal effective exchange rate is placed in the ordering ahead of the domestic prices. This implies that the nominal effective exchange rate responds contemporaneously to supply, demand and monetary policy shocks but not to price shocks. The exchange rate shocks are assumed to have a contemporaneous effect only on domestic inflation. Finally, the price variable is ordered last based on the assumption that the price variable is contemporaneously affected by all four shocks but price shocks have no contemporaneous impact on the other variables.

\section{Empirical Analysis}

\footnotetext{
${ }^{11}$ Hahn (2003) also orders the monetary policy variable (call rate) prior to exchange rate and prices by assuming that monetary policy reacts not to realized inflation but to expected inflation. In contrast, McCarthy (2000) orders the money supply last in a VAR model. Hence, the different ordering is also attempted to check the robustness and the result is reported in Section 5.2.
} 


\subsection{Data}

The five East Asian countries-Indonesia, Korea, Thailand, Malaysia and Singapore-are the sample countries of this study. ${ }^{12}$ The data are monthly from January 1993 to August 2005 except for Indonesia (March 1993 through August 2005) and Thailand (January 1993 through October 2004). All price series and the industrial production index $(2000=100)$ are seasonally adjusted. The nominal effective exchange rate index $(2000=100)$ is defined such that an increase in the index means depreciation. As a monetary policy variable, the seasonally adjusted base money is used for Indonesia, Korea and Thailand. Since the data of the base money is not available for Malaysia and Singapore, the narrow money (M1) is alternatively used for these countries. The output gap is defined by applying the HP filter to the natural $\log$ of the industrial production index. ${ }^{13}$ The data source for all the variables is IMF, International Financial Statistics, CD-ROM; IMF, Direction of Trade Statistics, CD-ROM; and the CEIC Asia Database. The details are described in Appendix 1.

$$
\text { *** Insert Table } 1 \text { around here. *** }
$$

The time series properties of variables are tested by the Augmented Dickey-Fuller Test (ADF) test and the Phillips-Perron (PP) test. The result is reported in Table 1 that shows that the oil price, three types of domestic prices, the monetary

\footnotetext{
${ }^{12}$ Taiwan, the Philippines and China are not studied because of the difficulty in obtaining the data.

${ }^{13}$ The HP filter is applied with much longer sample: the sample of January 1980 through August 2005 for Korea and Malaysia. Owing to the data availability for the industrial production index, the sample starts from March 1993 for Indonesia, from January 1989 for Singapore, and from January 1987 for Thailand.
} 
policy variables (base money and M1) and the nominal effective exchange rate appear to be non-stationary in level but stationary in first-differences for all countries. The result of unit-root tests also suggest that the output gap is an $\mathrm{I}(0)$ process. Thus, the endogenous variables in the baseline model, $x_{t}=\left(\Delta o i l_{t}, g a p_{t}, \Delta m_{t}, \Delta e f e x r_{t}, \Delta p_{t}\right)^{\prime}$, are assumed to be stationary and we proceed to the VAR estimation. ${ }^{14}$ The lag order of the VAR model is selected based on the likelihood Ratio (LR) test. ${ }^{15}$

\subsection{Exchange Rate Pass-Through to Domestic Prices}

This subsection discusses the degree of pass-through from the exchange rate shocks to domestic variables, especially the domestic price level, in five East Asian countries. The baseline model including CPI is estimated and then the impulse response function is analyzed. The accumulated impulse responses (solid line in Figures) are presented over a twenty-four months time horizon. All shocks are standardized to one-percent shocks and, hence, the vertical axis in Figures reports the approximate percentage change in domestic prices in response to a one percent shock. The dotted line in Figures denotes a two standard error confidence band around the estimate.

\footnotetext{
*** Insert Figure 4 around here. ***
}

Figure 4 shows the response of CPI, base money and output gap to a

\footnotetext{
${ }^{14}$ Previous studies suggest to including in a VAR the output gap in level together with other variables in first-differences. Hence, we conduct the structural VAR analysis rather than cointegration tests.

${ }^{15}$ The lag order of the baseline mode is as follows: Indonesia (4), Korea (2), Thailand (6), Singapore (8) and Malaysia (3).
} 
one-percent exchange rate shock. First, in terms of impacts from the exchange rate to inflation, the following differences among the countries are observed. As for a response of CPI to the exchange rate shock, Indonesia exhibits a very large response to a typical exchange rate shock. The CPI response to exchange rate in Korea and Thailand is also positive and statistically significant, but the degree of response is far smaller than that in Indonesia. The CPI response to the exchange rate shock in Malaysia is not statistically significant and much smaller than that in Korea and Thailand. Singapore, which was relatively immune to the currency crisis, indicates an insignificant response to the exchange rate shock.

Second, in terms of monetary base responses to a one percent exchange rate shock, the following cross-country difference is observed. The response of the base money to the exchange rate shock is also significantly positive and quite large in Indonesia, which indicates that the Bank Indonesia reacted to currency depreciation by increasing the base money. Among other crisis-hit countries, Korea and Thailand show negative and insignificant responses to the exchange rate shock, though only the initial response is positive and significant in Korea. Malaysia also exhibits the negative response but it is statistically significant. Third, the response of the output gap to a one percent exchange rate shock is very large and negative in all countries except Singapore, but the response is statistically significant only in Indonesia.

Overall, the response of domestic variables to the exchange rate shock is far larger and significant in Indonesia than in other countries. The response of CPI to the exchange rate shock is positive and significant in Korea and Thailand, but the degree of exchange rate pass-through is much smaller in these countries than in Indonesia. We have also found that the Bank Indonesia expanded base money in response to the exchange rate shock, which also contrasts markedly with the other countries. 
Although the Asian-currency crisis affected all these countries, Indonesia stood out in how directly the exchange rate shock caused a disruption in domestic economic management, monetary accommodation, higher inflation and output cut. Other countries used monetary policy more prudently so that the domestic inflation rate did not rise sharply. This shows that the economic malaise in Indonesia was partly caused not only by a contagion of crises from neighboring countries but by economic policy mistakes in reaction to the initial shock of exchange rate depreciation.

\subsection{Pass-Through Effects on Different Domestic Prices}

In considering the pass-through of exchange rate shocks into domestic prices, the pass-through effects on several types of domestic prices and the interaction between them are worth investigating. Previous studies, among others McCarthy (2000), Hahn (2003) and Faruqee (2004), attempted to examine the pass-through of exchange rate shocks on domestic prices at different stages of distribution. The larger the share of tradable goods in a certain price index, the more likely the effect of shocks is to be passed through to the price index. By comparing the import price index (IMP), the producers price index (PPI) and the consumer price index (CPI), it becomes possible for us to determine whether and how much the domestic reactions to exchange rate shocks mitigated or aggravated the external shocks. It is expected that the import price index exhibits the largest degree of pass-through while CPI shows the least. To make a rigorous analysis of exchange rate pass-through into prices at different stages, we first estimate the baseline model including not CPI but PPI or IMP and compare the results of pass-through across three prices. Second, we extend the baseline model to a 7-variable VAR by including three price variables together to investigate the extent of transmission in shocks across these prices. 
Figure 5 reports the response of IMP and PPI to a one-percent exchange rate shock. ${ }^{16}$ As expected, the response of IMP and PPI to the exchange rate shock is significantly higher than that of CPI in both IMP and PPI for all countries except Singapore. It is also confirmed that the degree of pass-through is higher in IMP than in PPI for all countries. Interestingly, the Indonesia's response is far higher than that of other countries for both IMP and PPI.

In sum, the degree of pass-through is highest in the import price index, followed by PPI, and the lowest in CPI among the East Asian countries affected by the crisis. It is important to note that price responses in Indonesia are by far the largest, and the part of the reasons is its monetary accommodation to the exchange rate shocks that aggravated the inflation.

Next, to investigate further the above findings, we use a 7-variable VAR with the vector of $x_{t}=\left(\Delta \text { oil }_{t}, \operatorname{gap}_{t}, \Delta m_{t}, \Delta e f e x r_{t}, \Delta i m p_{t}, \Delta p p i_{t}, \Delta c p i_{t}\right)^{\prime}$ where $i m p_{t}, p p i_{t}$ and $\mathrm{cpi}_{t}$ denote the import price index (or import unit value), PPI and CPI, respectively. To identify the structural shocks under the 7-variable VAR, we employ the following order in Choleski decomposition: ${ }^{17}$

\footnotetext{
${ }^{16}$ The response of Malaysian import price index (IMP) to the exchange rate shock is not presented owing to the difficulty in obtaining the data.

${ }^{17}$ The lag order of the 7-variable VAR is as follows: Indonesia (5), Korea (4), Thailand (3) and Singapore (8). The zero restrictions imposed in (2) are similar to Hahn (2003) and McCarthy (2000).
} 


$$
\left(\begin{array}{l}
u_{t}^{\text {oil }} \\
u_{t}^{\text {gap }} \\
u_{t}^{m} \\
u_{t}^{\text {efexr }} \\
u_{t}^{i m p} \\
u_{t}^{\text {ppi }} \\
u_{t}^{\text {cpi }}
\end{array}\right)=\left(\begin{array}{ccccccc}
S_{11} & 0 & 0 & 0 & 0 & 0 & 0 \\
S_{21} & S_{22} & 0 & 0 & 0 & 0 & 0 \\
S_{31} & S_{32} & S_{33} & 0 & 0 & 0 & 0 \\
S_{41} & S_{42} & S_{43} & S_{44} & 0 & 0 & 0 \\
S_{51} & S_{52} & S_{53} & S_{54} & S_{55} & 0 & 0 \\
S_{61} & S_{62} & S_{63} & S_{64} & S_{65} & S_{66} & 0 \\
S_{71} & S_{72} & S_{73} & S_{74} & S_{75} & S_{76} & S_{77}
\end{array}\right)\left(\begin{array}{l}
\varepsilon_{t}^{\text {oil }} \\
\varepsilon_{t}^{\text {gap }} \\
\varepsilon_{t}^{m} \\
\varepsilon_{t}^{\text {efexr }} \\
\varepsilon_{t}^{i m p} \\
\varepsilon_{t}^{p p i} \\
\varepsilon_{t}^{c p i}
\end{array}\right) .
$$

\section{*** Insert Figure 6 around here. ${ }^{* * *}$}

The primary objective of this 7-variable VAR model is to investigate to what degree shocks are transmitted from one domestic price index to another, in addition to the exchange rate shock to each domestic price. The result will be compared to those obtained in the baseline 5-variable models. Figure 6 shows that each response of IMP, PPI and CPI is very similar to the result obtained in the baseline model. Second, the response of PPI to a one-percent import price shock is significantly positive in Korea and Singapore at least for the first seven months. The response of PPI to the import price shock is positive in Indonesia and Thailand, but the response is not significant in Indonesia and significant only for 2-3 months in Thailand. The insignificant response of PPI in Indonesia is perhaps due to the data problem. Specifically, the import price index is not available in Indonesia and the import unit value is used as an alternative. Therefore Indonesian results involving IMP are not directly comparable to others. Third, the response of CPI to a one-percent PPI shock is significantly positive in Indonesia for the first eight months. In contrast, only the initial response is significantly positive and the degree of response is far smaller in Korea, Thailand and Singapore than that in Indonesia. The response of CPI to even domestic shocks is much 
more persistent in Indonesia.

In sum, the pass-through of exchange rate shocks to IMP and PPI is significantly positive in all countries except Singapore. The degree of the pass-through to a one-percent exchange rate shock varies across the different stages of distribution, i.e., the pass-through effect of the exchange rate shock is the largest on the import price index (IMP), the second on PPI and the smallest on CPI, as predicted by theory. The degree of pass-through is found to be much larger in Indonesia than in other countries in each stage of the distribution channel. Although the pass-through into CPI is also significantly positive in Korea and Thailand, the degree of pass-through is much smaller in these countries than in Indonesia. Such difference in the degree of pass-through between Indonesia and other countries might be attributable partly to monetary policy accommodative reactions and partly to the shock transmission from PPI to CPI, because only Indonesia exhibits a large and significant response of CPI to PPI shocks.

\subsection{Impulse Response Functions}

As mentioned earlier, the degree of responsiveness of domestic prices to the exchange rate shock has important implications for the economic recovery process among the crisis-hit countries. An increase in domestic inflation immediately after a sharp depreciation of the currency would prevent the improvement in the price competitiveness of exports. It causes a delay in economic recovery after the currency crisis. The speed of recovery seems to depend critically upon the inflation performance after the currency depreciation.

During the crisis period, the exchange rate of the crisis-hit countries depreciated sharply. A question is whether such a large depreciation caused a high 
inflation in those countries. As discussed above, however, crisis-hit East Asian countries exhibited a relatively low level of CPI inflation except for Indonesia. The relatively milder inflation may be partly due to a severe downturn of domestic demand. Figure 4 supports the above discussion, because the crisis-hit countries show the large negative response of output gap to the exchange rate shock though it is statistically significant only in Indonesia.

The central bank's reaction to the exchange rate shock appears to be very different between Indonesia and the other crisis-affected countries. Specifically, it is only Indonesia that responded to the exchange rate shock by increasing the base money significantly (Figure 4), which conforms to the fact that Indonesia's base money growth was far greater after the crisis than other crisis-hit countries. ${ }^{18}$ In Indonesia, the currency crisis induced the domestic financial crisis as well as internal political instability, which deteriorated the supply side of the economy. Under the framework of the AD-AS model, the AS curve shifted leftward to a large extent in Indonesia. As the $\mathrm{AD}$ curve shifts rightward at the same time due to an increase in the domestic money supply, not only a fall in GDP growth rates but also a far larger increase in inflation rates occurred simultaneously. The above arguments are supported by the results of impulse response functions.

Figure 7 shows the impulse response of CPI and the output gap to a one-percent monetary policy shock. It is only in Indonesia that the response of CPI to the monetary policy shock is significantly positive and the corresponding response of output gap is significantly negative. ${ }^{19}$ Furthermore, we plot in Figure 8 the series of

\footnotetext{
${ }^{18}$ McLeod (2003) compares the increase in base money between Indonesia, Korea, Thailand and Malaysia, and reaches the same conclusion.

${ }^{19}$ As shown in Figure 4, the response of CPI to exchange rate shocks is significantly positive and the corresponding response of output gap is significantly negative, which also supports our
} 
structural shocks to base money and exchange rate obtained from the VAR estimation of the baseline model. Only in Indonesia, we observe a high contemporaneous correlation between the two shocks kinds of during the crisis period, reflecting the Bank Indonesia’s monetary policy reaction to the exchange rate shock. ${ }^{20}$

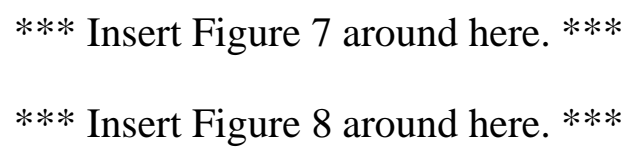

To examine further the above discussion, a variance decomposition analysis is employed. Figure 9 reports the result of variance decomposition of CPI and output gap over a forecast horizon of twenty-four months in order to check the relative importance of each shock in explaining forecast errors of CPI and output gap. ${ }^{21}$ As for the variance of CPI, the exchange rate shock is an important determinant in Indonesia and Korea, where about 40 percent of variation are accounted for by the exchange rate shock in Indonesia and about 30 percent in Korea. Interestingly, the monetary policy shock is the second important determinant for the first nine months in Indonesia, implying that the initial response of CPI is largely affected by the monetary policy shock as well as the exchange rate shock in Indonesia. Prices are quite sensitive to the monetary policy in Indonesia. In Thailand, Malaysia and Singapore,

argument.

${ }^{20}$ The correlation between monetary policy and exchange rate shocks over the sample period is very high in Indonesia (0.77) while close to zero or negative in other countries: Korea (-0.12), Thailand (-0.13), Singapore (-0.21) and Malaysia (0.11).

${ }^{21}$ The contributions of its own price shock (for variance decomposition of CPI) and own output gap shock (for variance decomposition of output gap) are not reported in Figure 9 for the sake of clearness. 
exchange rate and other three shocks account for only a small share in variance of CPI, which indicates that its own price (CPI) shock is the most important in explaining its variation. Regarding the variance of output gap, the oil price shock appears to be the most important determinant in Korea, Thailand and Malaysia. In contrast, monetary, exchange rate and CPI shocks are more important in explaining the variation of output gap in Indonesia. The last finding may be explained by the fact that Indonesia is oil-producing nations and negative impact of oil price increases on aggregate demand is partially mitigated by profits of oil-producing companies. It is also revealed that Indonesian output was largely affected by nominal variables, the exchange rate and CPI. This empirical observation is consistent with a view that non-performing loans resulting from the currency mismatch, credit crunch from the weak banking system played a role in the recession of Indonesia.

*** Insert Figure 9 around here. ***

Thus, our empirical results suggest that a remarkable difference in the post-crisis inflation performance between Indonesia and other crisis-affected countries is attributed to the Bank Indonesia's monetary policy reaction. The remaining question is why the base money growth was extremely high in Indonesia. Why did the Bank Indonesia increase the base money so much, risking high inflation in the wake of the currency crisis? Although not quantitatively shown in the VAR analysis of this paper, such an increase in the base money growth can be explained by the impact of nonperforming loans problem and reactions of the central bank. In the early stage of the Asian currency crisis, some commercial banks and non-bank financial institutions became insolvent as many corporations failed under difficult 
economic conditions. Some banks tried to keep corporations alive by providing liquidity, and the central bank, in turn, provided liquidity to commercial banks so that banks would not fail. The liquidity support resulted in an expansion of bank loans and M2. The liquidity support happened in different Asian countries in the different stage of currency crisis (the first in Thailand, and Indonesia and Korea much later), and with different magnitude. Indonesia had certainly the most severe case in liquidity provision, as most banks had negative equity position before massive capital injection by the government in 1998. Efforts of keeping banks alive and maintaining the financial stability, some necessary and some misguided, explain why M2 were increasing in Indonesia and resulted in inflation.

\section{Robustness}

\subsection{Sub-samples}

We have analyzed the degree of pass-through of exchange rate and other types of shocks using the baseline model, $x_{t}=\left(\Delta \operatorname{oil}_{t}, \operatorname{gap}_{t}, \Delta m_{t}, \Delta e f e x r_{t}, \Delta p_{t}\right)^{\prime}$, with the sample of 1993M1 through 2005M8. However, one may suspect the economic structure and policy regimes may have changed during the 12 years, especially after the currency crisis of 1997-98, in many Asian countries. The currency crisis drove the countries to abandon the de facto US dollar peg policy and to adopt more flexible exchange rate policy such as managed floating. So, we conduct the sub-sample analysis using the 5-variable baseline model, focusing on the sample starting from 1997M7, the month of Thai baht large depreciation. In addition, we may try the different ordering of variables in a VAR model to check the robustness of the above empirical results. 
The first two rows in Figure 10 report the results obtained from the baseline model with the sub-sample from 1997M7 to 2005M8. Owing to the space limitation, only responses of CPI to the monetary policy shock and the exchange rate shock are presented. The result is quite similar to that with the full sample from 1993M1 to 2005M8, although the degree of CPI response to exchange rate shocks becomes smaller in Korea and Thailand. The response of CPI to monetary policy shocks becomes even negative in Korea and Thailand when using the sub-sample. In contrast, the CPI response to monetary policy shocks in Indonesia becomes larger and statistically significant over the 24 months. The excessive monetary expansion by the Bank Indonesia and its impact on domestic inflation become more evident when using the sub-sample for a VAR analysis.

\subsection{Different Ordering}

The result of VAR analysis, such as variance decomposition and impulse responses, is sensitive to the ordering of variables. Two orderings different from the benchmark are estimated in order to check the sensitivity of the above results to the assumption of variable ordering. First, output gap is placed the fourth instead of the second in the ordering. When the monetary policy is decided, it is assumed that contemporaneous information of the exchange rate shock and output gap is either not available or ignored. The nominal exchange rate shocks affect output gap contemporaneously, but not vice versa. Accordingly, the "Alternative Model 1" is $x_{t}=\left(\Delta \text { oil }_{t}, \Delta m_{t}, \Delta e f e x r_{t}, g a p_{t}, \Delta p_{t}\right)^{\prime}$. Second, the ordering of money and the exchange rate may be switched from the baseline model. This amounts to an 
assumption that exchange rate shocks at monthly frequency are not affected by monetary policy shock contemporaneously. Thus, this “Alternative Model 2" is $x_{t}=\left(\Delta \text { oil }_{t}, \text { gap }_{t}, \Delta e f e x r_{t}, \Delta m_{t}, \Delta p_{t}\right)^{\prime}$.

The results of CPI responses to both the exchange rate and monetary policy shocks are reported in Figure 10. For the comparison purpose, the results using the sub-sample are reported. The third and fourth rows present the results of the Alternative Model 1, which shows that the CPI response is quite similar between the baseline model and the alternative model. The fifth and sixth rows exhibit the results of CPI response obtained from the Alternative Model 2. Again the results are similar to those of the other models, although the Indonesia's CPI response to monetary policy shocks becomes insignificant after four months.

Overall, we have confirmed that the difference in the degree of CPI response to exchange rate and monetary policy shocks is more evident between Indonesia and other crisis-affected countries if we use the shorter sub-sample period for estimation. The result of impulse response is quite similar even if we use the different VAR orderings.

\section{Concluding Remarks}

In this paper, the pass-through effects of the exchange rate changes on imported prices, producer (wholesale) prices, and consumer prices for East Asian countries were analyzed. The VAR analysis of the exchange rate pass-through has revealed several new important facts. First, the degree of pass-through to the exchange rate shock varies across the different price indices: the pass-through effect is the largest for the import price index, the second for PPI and the smallest on CPI. Second, the degree of domestic price response to the exchange rate shock is by far the 
largest in Indonesia compared to other crisis-hit East Asian countries. The CPI response to the exchange rate shock is particularly larger in Indonesia than in other countries. Moreover, only Indonesia exhibits a large and significant response of CPI to the PPI shock, implying the smooth transmission of shocks from PPI to CPI. Third, a notable difference in the post-crisis inflation performance between Indonesia and other crisis-affected countries is attributable to the Bank Indonesia's monetary policy reaction. It is only in Indonesia that both the impulse responses of monetary base to the exchange rate shock and those of CPI to the monetary shock are positive, large and statistically significant. Fourth, when focusing on the post-crisis period, the difference in the pass-through effect into CPI becomes more evident between Indonesia and other crisis-affected countries.

The pass-through examination using the VAR technique provides an important insight into a crisis propagation mechanism in emerging market economies. When depreciation results in domestic inflation, a crisis become much more complicated and the recovery process will be delayed. The estimated results show that the Indonesia's disappointing recovery process after the crisis can be at least partly attributable to the high pass-through of exchange rate shocks to CPI, the shock transmission from PPI to CPI, and the central bank's monetary policy reaction to depreciation. Domestic inflation of Indonesia had offset price competitiveness that resulted from a large nominal depreciation relative to neighboring countries and erased any possibility of nominal appreciation that would help damaged balance sheets of corporations and banks. 


\section{Appendix 1: Data Description}

\section{$\underline{\text { A. Common Variable }}$}

Oil price: The US dollar-basis oil price index ( $2000=100$, monthly series) is taken from IMF, International Financial Statistics (IFS), CD-ROM.

\section{B. Country-Specific Variables}

\section{B1. Indonesia}

Base money: The monthly series of base money is used from the CEIC Asia Database. Seasonality is adjusted using the Census X12 program.

Nominal effective exchange rate: The monthly series of the nominal effective exchange rate index $(2000=100)$ is constructed by the weighted average of eighteen major trading partner countries (exports plus imports). The bilateral exchange rate and the trade share are, respectively, obtained from IFS and IMF, Direction of Trade Statistics, CD-ROM.

Industrial production index: The monthly series of the manufacturing industrial production index $(2000=100)$ is taken from the CEIC Asia Database. Seasonality is adjusted using the Census X12 program.

CPI: The monthly series of CPI $(2000=100)$ is taken from IFS. Seasonality is adjusted using the Census X12 program.

PPI: The monthly series of wholesale price index (including petroleum; $2000=100$ ) is taken from IFS. Seasonality is adjusted using the Census X12 program.

Import prices: The monthly series of the import unit value index $(2000=100)$ is constructed by dividing the total import value by the total import volume. The US dollar based total import values are converted into local currency values by using an index of bilateral nominal exchange rate of rupiah vis-à-vis the US dollar $(2000=1.00)$. 
The data for the total import value and volume are obtained from the CEIC Asia Database. Seasonality is adjusted using the Census X12 program.

B2. Korea

Base money: The monthly series of base money is used from the CEIC Asia Database. Seasonality is adjusted using the Census X12 program.

The monthly series of the nominal effective exchange rate index $(2000=100)$ is constructed by the weighted average of twenty major trading partner countries (exports plus imports). The bilateral exchange rate and the trade share are, respectively, obtained from IFS and IMF, Direction of Trade Statistics, CD-ROM.

Industrial production index: The monthly series of the industrial production index $(2000=100)$ is taken from the CEIC Asia Database. Seasonality is adjusted using the Census X12 program.

CPI: The monthly series of CPI $(2000=100)$ is taken from the CEIC Asia Database. Seasonality is adjusted using the Census X12 program.

PPI: The monthly series of producer price index (including all commodities and services; 2000 $=100$ ) is taken from the CEIC Asia Database. Seasonality is adjusted using the Census X12 program.

Import prices: The monthly series of the import price index (the Korean won basis; $2000=100$ ) is obtained from the CEIC Asia Database. Seasonality is adjusted using the Census X12 program.

\section{B3. Malaysia}

Money supply: The monthly series of money supply, M1, is used from the CEIC Asia Database. Seasonality is adjusted using the Census X12 program 
Nominal effective exchange rate: The monthly series of the nominal effective exchange rate index $(2000=100)$ is obtained from IFS.

Industrial production index: The monthly series of the industrial production index $(2000=100)$ is taken from the CEIC Asia Database. Seasonality is adjusted using the Census X12 program.

CPI: The monthly series of CPI $(2000=100)$ is taken from the CEIC Asia Database. Seasonality is adjusted using the Census X12 program.

PPI: The monthly series of producer price index (for goods in the domestic economy; 2000=100) is taken from the CEIC Asia Database. Seasonality is adjusted using the Census X12 program.

\section{B4. Singapore}

Money supply: The monthly series of money supply, M1, is used from the CEIC Asia Database. Seasonality is adjusted using the Census X12 program.

Nominal effective exchange rate: The monthly series of the nominal effective exchange rate index $(2000=100)$ is obtained from IFS.

Industrial production index: The monthly series of the industrial production index $(2000=100)$ is taken from the CEIC Asia Database. Seasonality is adjusted using the Census X12 program.

CPI: The monthly series of CPI $(2000=100)$ is taken from IFS. Seasonality is adjusted using the Census X12 program.

PPI: The monthly series of wholesale price index $(2000=100)$ is taken from IFS. Seasonality is adjusted using the Census X12 program.

Import prices: The monthly series of the import price index $(2000=100)$ is obtained from IFS. Seasonality is adjusted using the Census X12 program. 


\section{B5. Thailand}

Base money: The monthly series of base money is used from the CEIC Asia Database. Seasonality is adjusted using the Census X12 program.

Nominal effective exchange rate: The monthly series of the nominal effective exchange rate index $(2000=100)$ is obtained from the CEIC Asia Database.

Industrial production index: The monthly series of the manufacturing production index $(2000=100)$ is taken from the CEIC Asia Database. Seasonality is adjusted using the Census X12 program.

CPI: The monthly series of CPI $(2000=100)$ is taken from IFS. Seasonality is adjusted using the Census X12 program.

PPI: The monthly series of producer price index $(2000=100)$ is taken from IFS. Seasonality is adjusted using the Census X12 program.

Import prices: The monthly series of the import value index (the Thai Baht basis; $2000=100$ ) is obtained from the CEIC Asia Database. The data is available from January 1996. Seasonality is adjusted using the Census X12 program. 


\section{References}

Azis, I. J. and W. Thorbecke, 2004, "The Effects of Exchange Rate and Interest Rate Shocks on Bank Lending in Indonesia,” Economics and Finance in Indonesia, 52(3), pp.279-295.

Campa, J. M. and L. S. Goldberg, 2005, "Exchange Rate Pass Through into Import Prices,” Review of Economics and Statistics, 87(4), pp.679-690.

Campa, J. M., L. S. Goldberg and J. M. González-Mínguez, 2005, “Exchange Rate Pass-Through to Import Prices in Euro Area,” NBER Working Paper 11632, National Bureau of Economic Research.

Caporale, G. M., A. Cipollini and P. O. Demetriades, 2005, “Monetary Policy and the Exchange Rate during the Asian Crisis: Identification through Heteroscedasticity,” Journal of International Money and Finance, 24, pp.39-53.

de Brouwer, G., 2003, “'Towards Improved Monetary Policy in Indonesia’: A Comment,” Bulletin of Indonesian Economic Studies, 39(3), pp.325-328.

Faruqee, H., 2004, "Exchange Rate Pass-Through in the Euro Area: The Role of Asymmetric Pricing Behavior,” IMF Working Paper WP/04/14, International Monetary Fund.

Feenstra, R. C., 1989, “Symmetric Pass-Through of Tariffs and Exchange Rates under Imperfect Competition: An Empirical Test,” Journal of International Economics, 27, pp.25-45.

Goldberg, L. S. and J. M. Campa, 2006, “Distribution Margins, Imported Inputs, and the Sensitivity of the CPI to Exchange Rates,” NBER Working Paper 12121, National Bureau of Economic Research.

Hahn, E., 2003, “Pass-Through of External Shocks to Euro Area Inflation,” Working Paper, 243, European Central Bank. 
Ito, T. and Y. Hashimoto, 2002, "High-Frequency Contagion of Currency Crises in Asia,” NBER Working Paper, No.9376, December (Last Revised February 24, 2005).

Ito, T., E. Ogawa and Y. N. Sasaki, 1998, "How Did the Dollar Peg Fail in Asia?” Journal of the Japanese and International Economies, 12, pp.256-304.

Knetter, M. M., 1989, "Price Discrimination by U.S. and German Exporters," American Economic Review, 79(1), pp.198-210.

Knetter, M. M., 1993, “International Comparison of Pricing-to-Market Behavior,” American Economic Review, 83(3), pp.473-486.

Marston, R. C., 1990, “Pricing to Market in Japanese Manufacturing,” Journal of International Economics, 29, pp.217-236.

McCarthy, J., 2000, "Pass-Through of Exchange Rates and Import Prices to Domestic Inflation in Some Industrialized Economies,” Staff Reports, 111, Federal Reserve Bank of New York.

McLeod, R. H., 2003, “Towards Improved Monetary Policy in Indonesia,” Bulletin of Indonesian Economic Studies, 39(3), pp.303-324.

Ohno, K., 1989, "Export Pricing Behavior of Manufacturing: a US-Japan Comparison,” International Monetary Fund Staff Papers, 36, pp.550-79.

Olivei, G. P., 2002, "Exchange Rates and the Prices of Manufacturing Products Imported into the United States,” New England Economic Review, Federal Reserve Bank of Boston, First Quarter, pp.3-18.

Otani, A., S. Shiratsuka and T. Shirota, 2005, "Revisiting the Decline in the Exchange Rate Pass-Through: Further Evidence from Japan's Import Prices,” IMES Discussion Paper No. 2005-E-6, Institute for Monetary and Economic Studies, Bank of Japan. 
Parsons, C. and K. Sato, 2006, “Exchange Rate Pass-Through and Currency Invoicing: Implications for Monetary Integration in East Asia,” forthcoming in The World Economy.

Sasaki, Y. N., 2005, "Pass-Through of Exchange Rates on Import Prices in East Asian Countries,” Keizai Kenkyu (The Papers and Proceedings of Economics), 132, The Society of Economics, Meiji Gakuin University, pp.23-33.

Toh, M-H and Ho, H-J, 2001, "Exchange Rate Pass-Through for Selected Asian Economies,” Singapore Economic Review, 46(2), pp.247-273. 
Table 1. Unit Root Tests

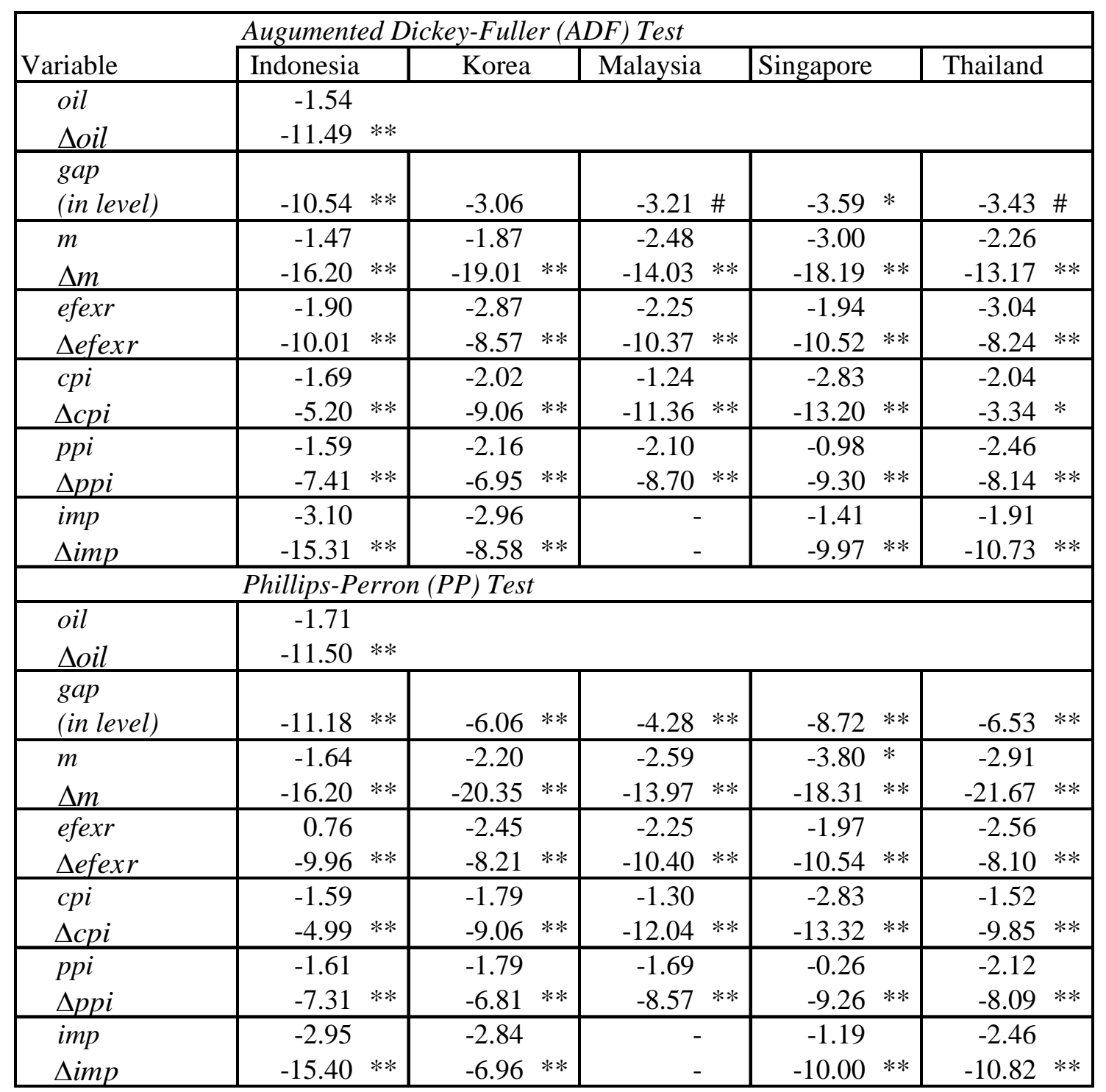

Notes: Double asterisks $\left({ }^{* *}\right)$, a single asterisk $\left({ }^{*}\right)$ and a sharp (\#), respectively, denote the significance at the one percent, five percent and ten percent level. Sample period: from January 1993 to August 2005. The null hypothesis of the ADF and PP tests is that the variable is nonstationary. For the level of variables, constant and time trend are included. For the first-difference of variables, only constant is included. 
Figure 1. Nominal Exchange Rate vis-à-vis the US Dollar $(1996=100)$

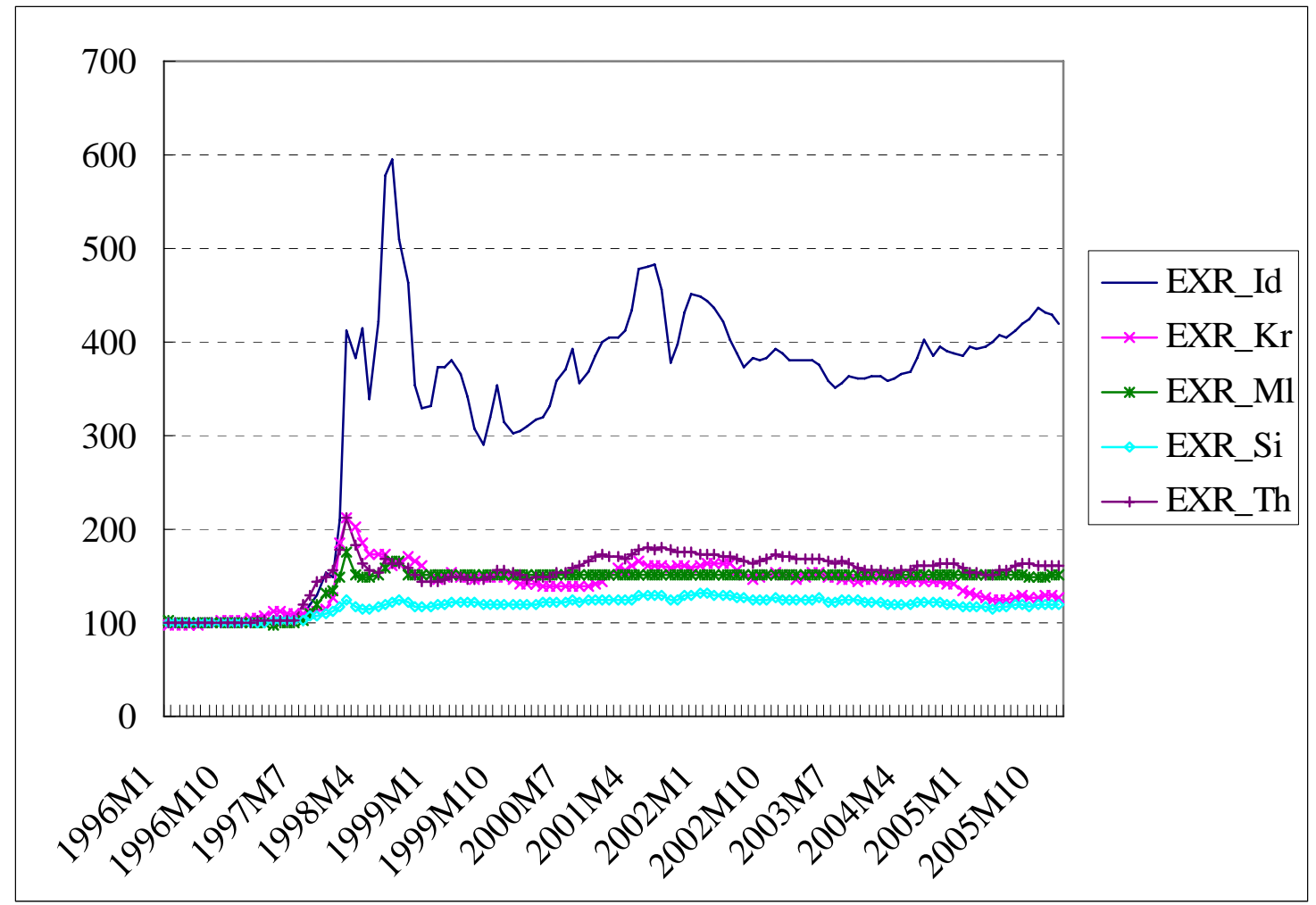

Note: Id (Indonesia), Kr (Korea), Ml (Malaysia), Si (Singapore) and Th (Thailand).

Sources: IMF, International Financial Statistics, CD-ROM; The CEIC Asia Database. 
Figure 2. CPI (1996=100): East Asian Countries

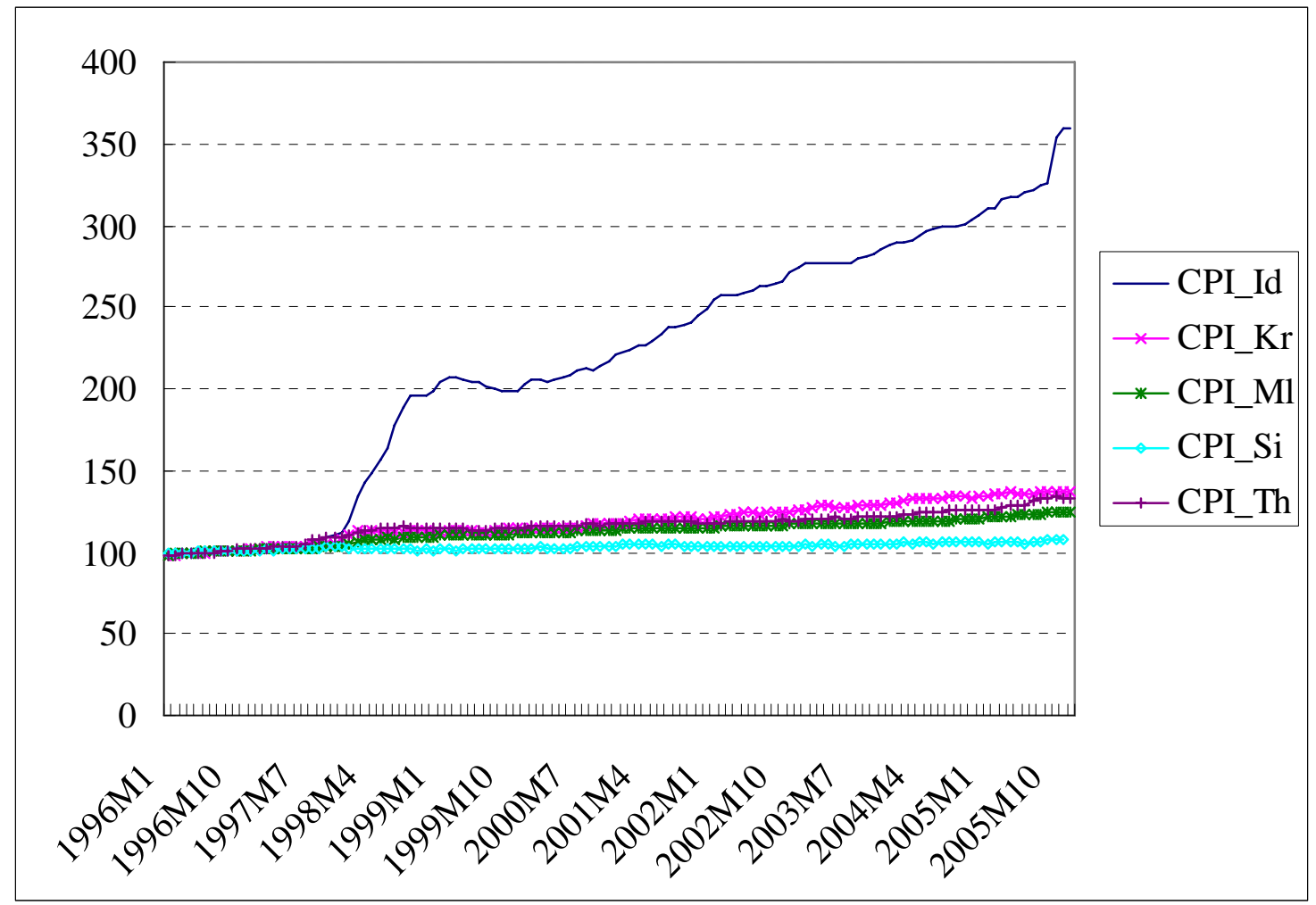

Note: Id (Indonesia), Kr (Korea), Ml (Malaysia), Si (Singapore) and Th (Thailand).

Sources: IMF, International Financial Statistics, CD-ROM; The CEIC Asia Database. 
Figure 3. Real Exchange Rate vis-à-vis the US Dollar (1996=100)

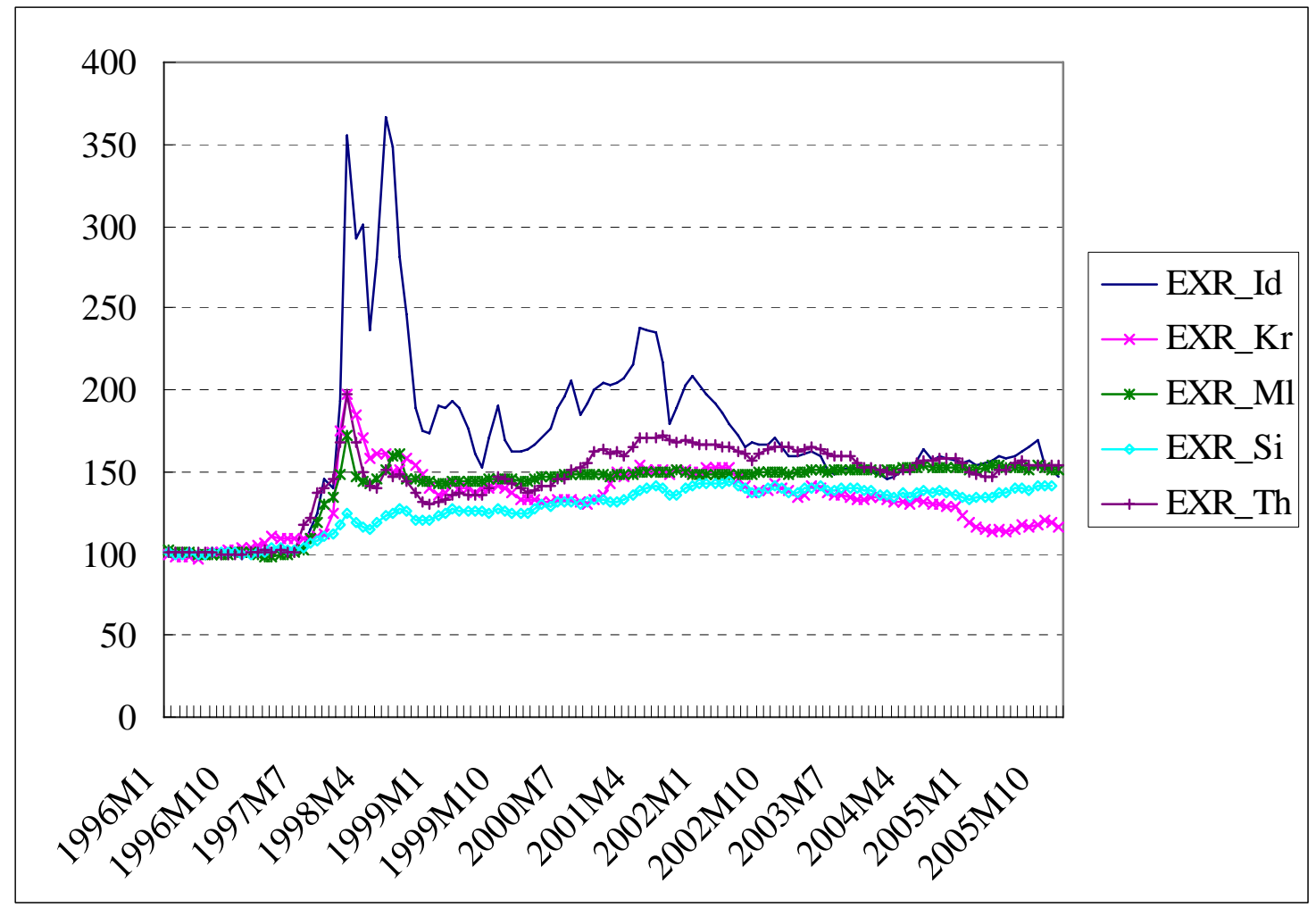

Note: Id (Indonesia), Kr (Korea), Ml (Malaysia), Si (Singapore) and Th (Thailand).

Sources: IMF, International Financial Statistics, CD-ROM; The CEIC Asia Database. 
Figure 4. Impulse Response to the Exchange Rate Shock

\section{Response of CPI}

(i) Indonesia

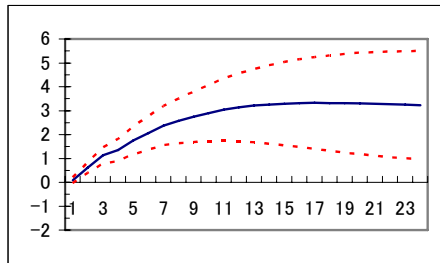

(ii) Korea

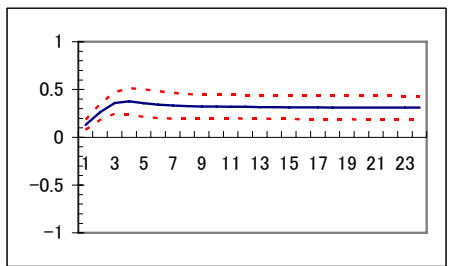

(iii) Thailand

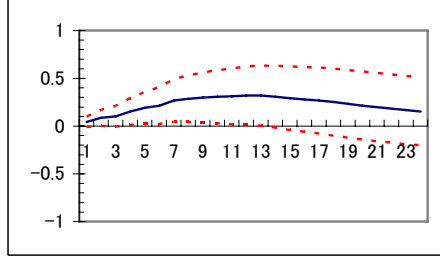

(iv) Singapore

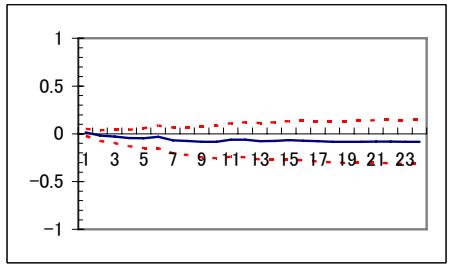

(v) Malaysia

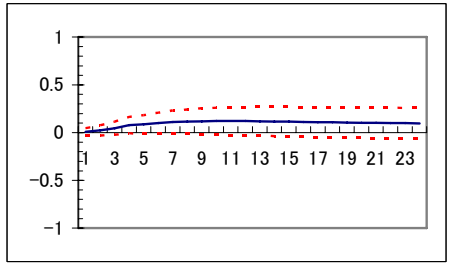

\section{Response of Base Money}

(i) Indonesia

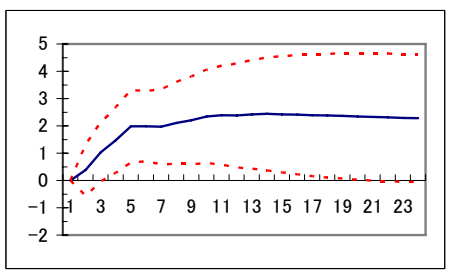

(ii) Korea

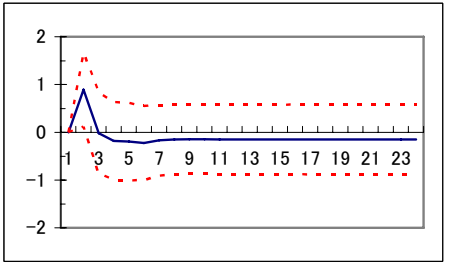

(iii) Thailand

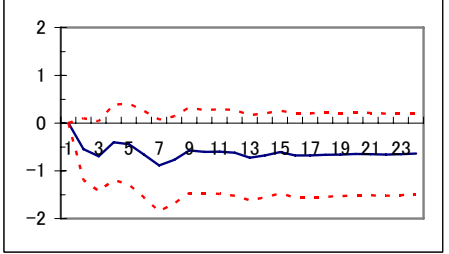

(iv) Singapore

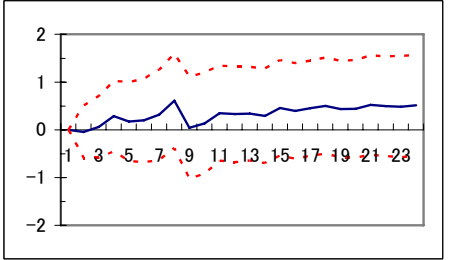

(v) Malaysia

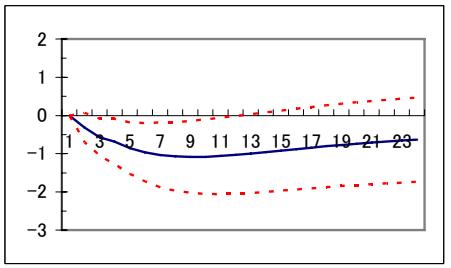

\section{Response of Output Gap}

(i) Indonesia

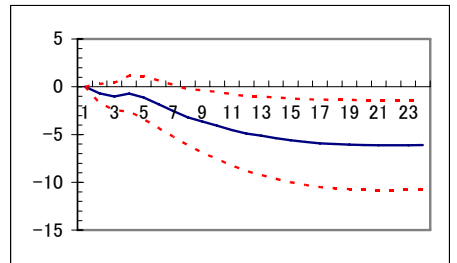

(ii) Korea

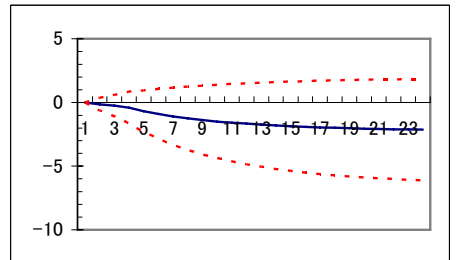

(iii) Thailand

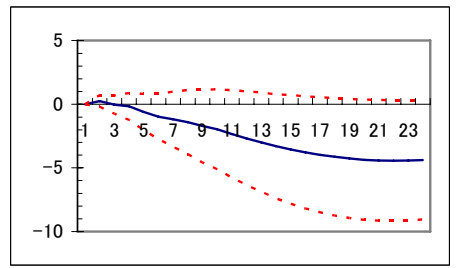

(iv) Singapore

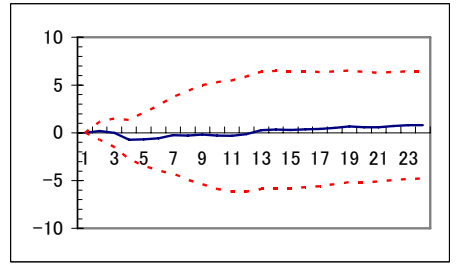

(v) Malaysia

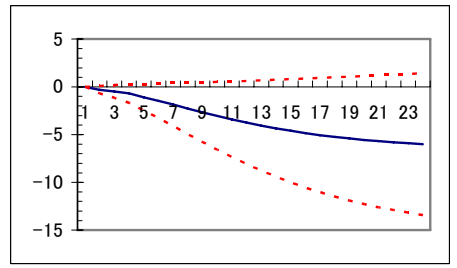

Notes: Baseline model (5-variable VAR). The accumulated impulse responses are presented. All shocks are standardized to one-percent shocks. The vertical axis indicates the approximate percentage change in response to a one percent exchange rate shock. The horizontal axis represents the time horizon (1 through 24 months). The dotted line denotes a two standard error confidence band around the estimate. 
Figure 5. Impulse Response of PPI and Import Prices to the Exchange Rate Shock

\section{Response of PPI}

(i) Indonesia

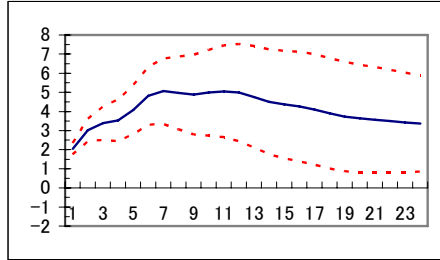

(ii) Korea

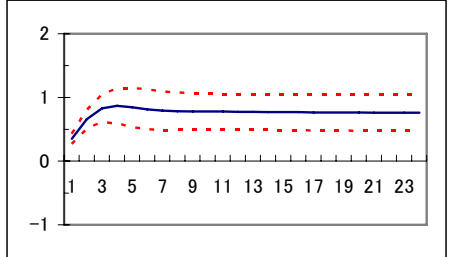

(iii) Thailand

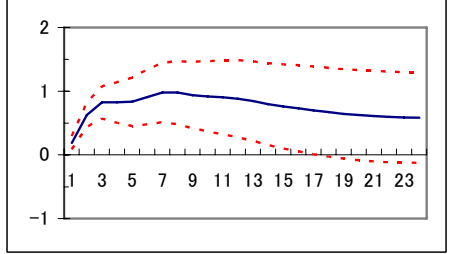

(iv) Singapore

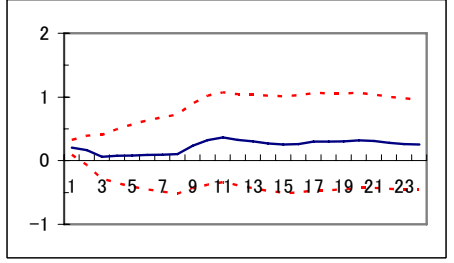

(v) Malaysia

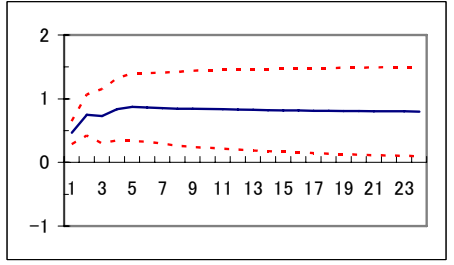

\section{Response of Import Prices}

(i) Indonesia

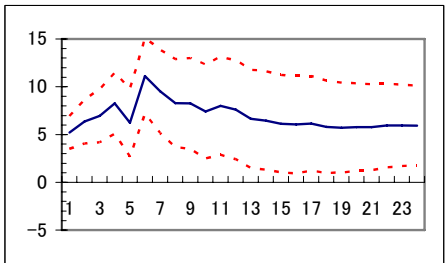

(ii) Korea

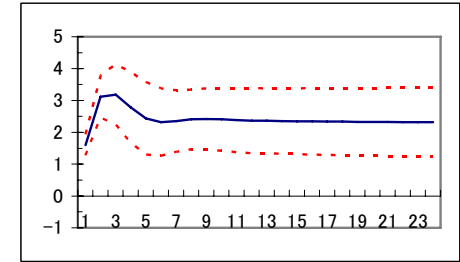

(iii) Thailand

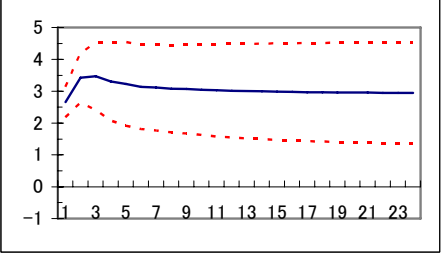

(iv) Singapore

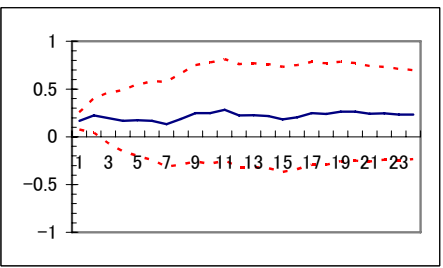

Notes: Baseline model (5-variable VAR). The accumulated impulse responses are presented. All shocks are standardized to one-percent shocks. The vertical axis indicates the approximate percentage change in response to a one percent exchange rate shock. The horizontal axis represents the time horizon (1 through 24 months). The dotted line denotes a two standard error confidence band around the estimate. 
Figure 6. Impulse Response to the Exchange Rate Shock: 7-Variable VAR
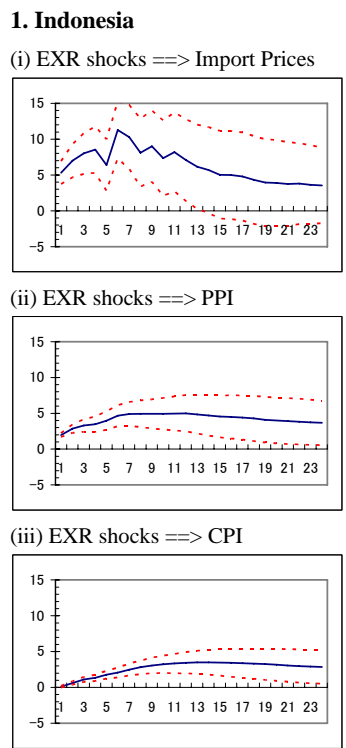

(iv) Import Price Shock ==> PPI

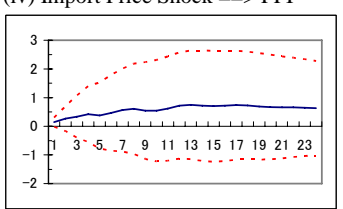

(v) PPI Shock ==> CPI

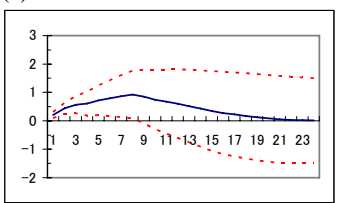

2. Korea

(i) EXR shocks ==> Import Prices

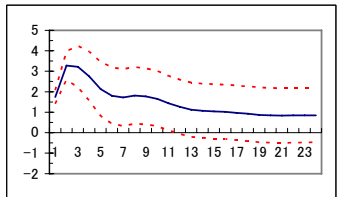

(ii) EXR shocks ==> PPI

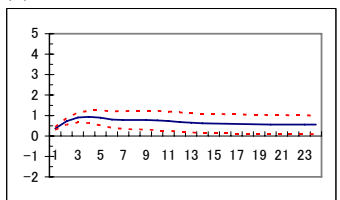

(iii) EXR shocks ==> CPI

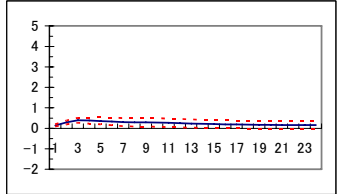

(iv) Import Price Shock ==> PPI

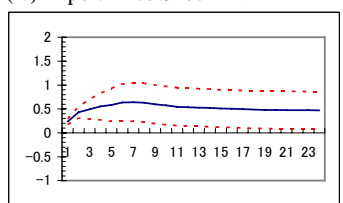

(v) PPI Shock ==> CPI

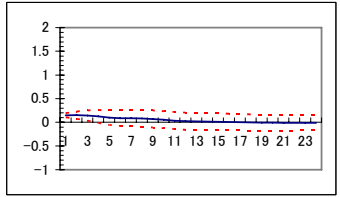

3. Thailand

(i) EXR shocks ==> Import Prices

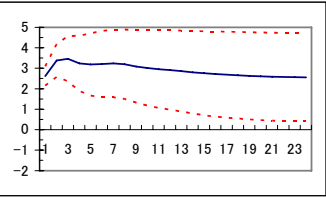

(ii) EXR shocks ==> PPI

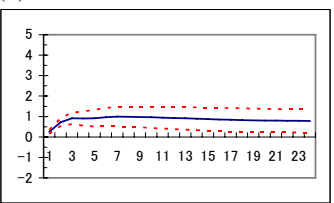

(iii) EXR shocks $==>$ CPI

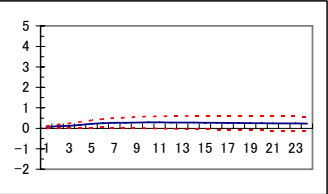

(iv) Import Price Shock ==> PPI

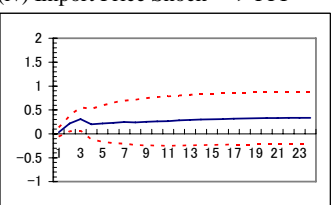

(v) PPI Shock ==> CPI

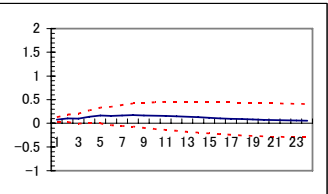

4. Singapore

(i) EXR shocks ==> Import Prices

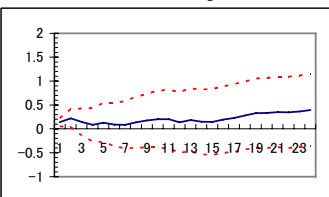

(ii) EXR shocks ==> PPI

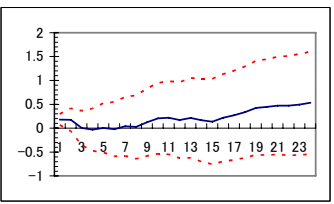

(iii) EXR shocks $==>$ CPI

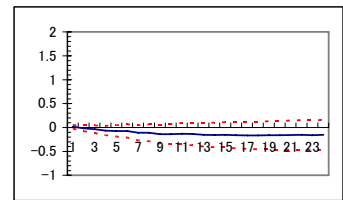

(iv) Import Price Shock ==> PPI

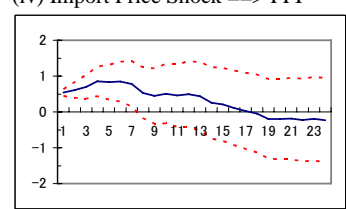

(v) PPI Shock ==> CPI

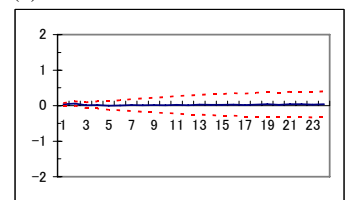

Notes: 7-variable VAR model. The accumulated impulse responses are presented. All shocks are standardized to one-percent shocks. The vertical axis indicates the approximate percentage change in response to a one percent exchange rate shock. The horizontal axis represents the time horizon (1 through 24 months). The dotted line denotes a two standard error confidence band around the estimate. 
Figure 7. Impulse Response to the Monetary Policy Shock

\section{Response of CPI}

(i) Indonesia

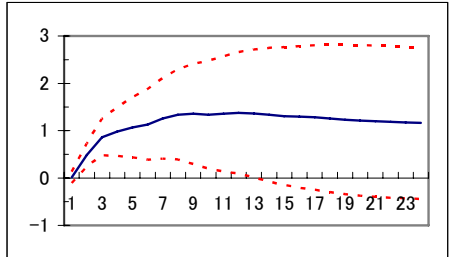

(ii) Korea

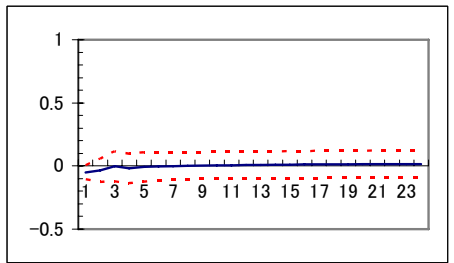

(iii) Thailand

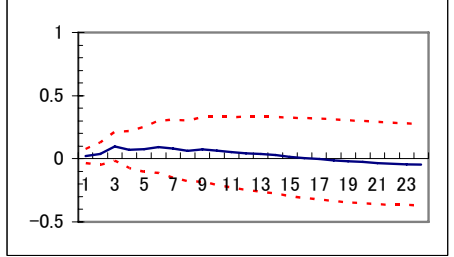

(iv) Singapore

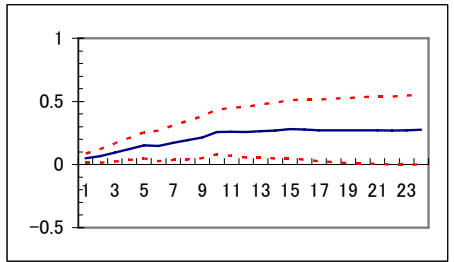

(v) Malaysia

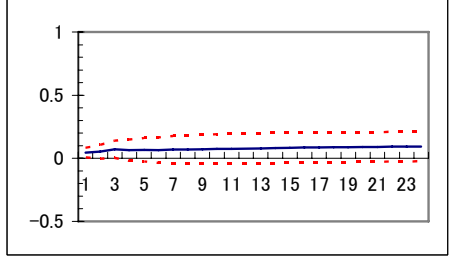

\section{Response of Output Gap}

(i) Indonesia

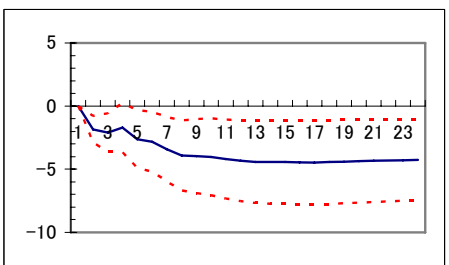

(ii) Korea

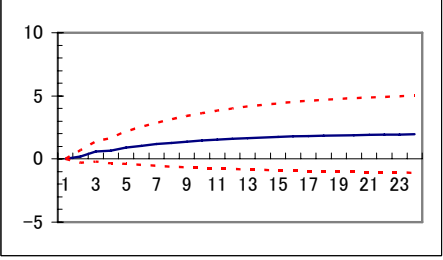

(iii) Thailand

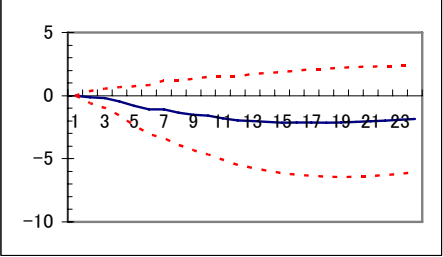

(iv) Singapore

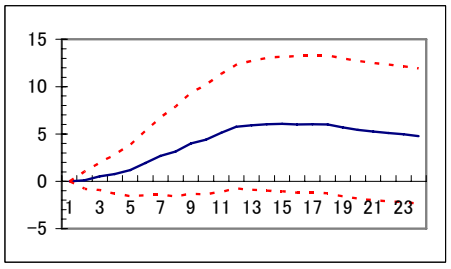

(v) Malaysia

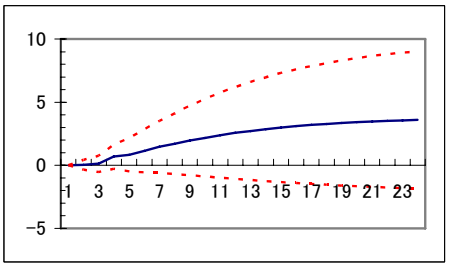

Notes: Baseline model (5-variable VAR). The accumulated impulse responses are presented. All shocks are standardized to one-percent shocks. The vertical axis indicates the approximate percentage change in response to a one percent exchange rate shock. The horizontal axis represents the time horizon (1 through 24 months). The dotted line denotes a two standard error confidence band around the estimate. 
Figure 8. Time Series of Structural Shocks to Base Money and Exchange Rate

(i) Indonesia

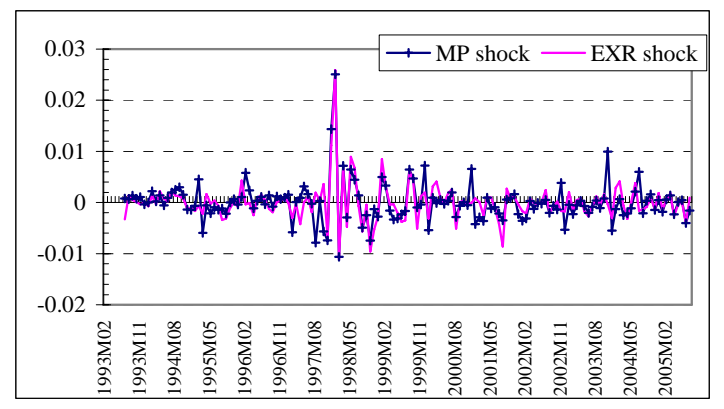

(ii) Korea

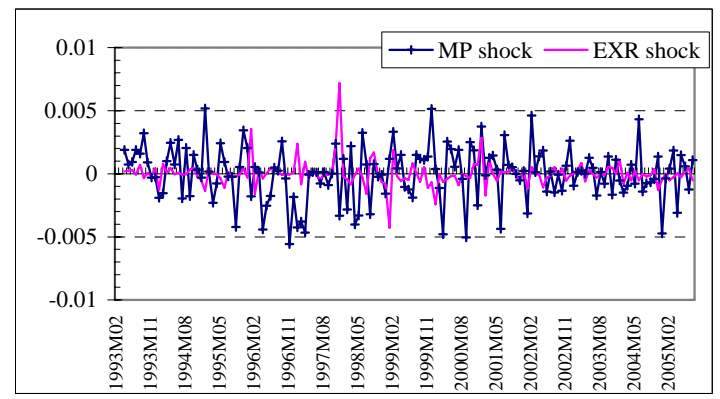

(iv) Singapore

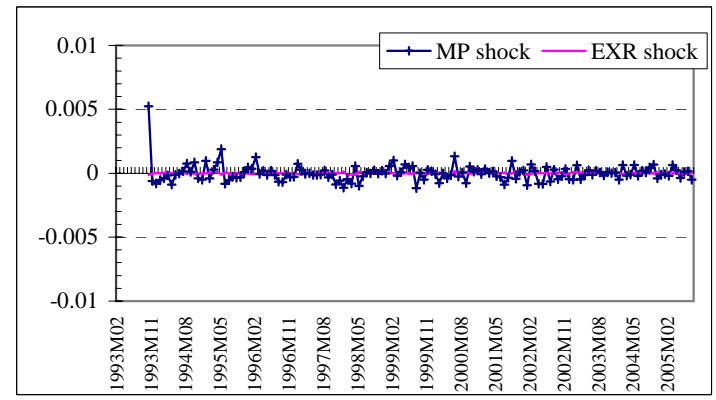

(v) Malaysia

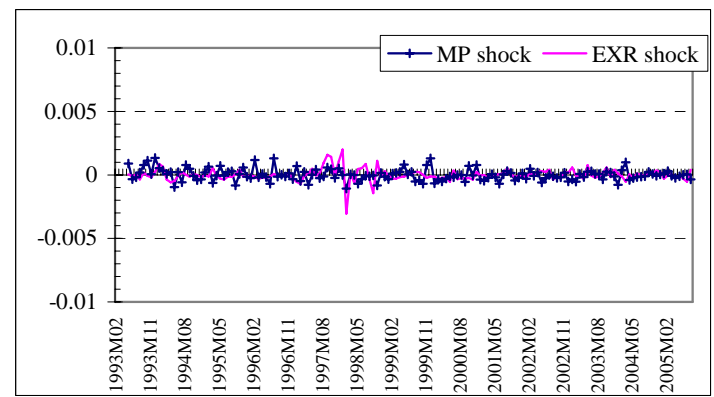

(iii) Thailand

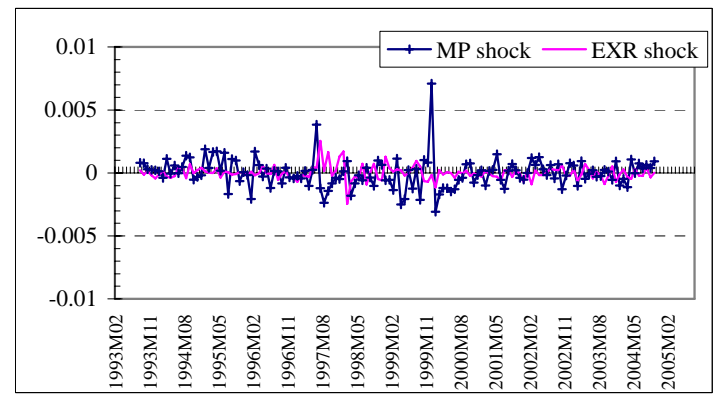

Notes: MP shock and EXR shock denote monetary policy shock and exchange rate shock, respectively. The series of shocks are obtained from the baseline model that includes CPI as a price variable. 
Figure 9. Variance Decomposition (VD) of CPI and Output Gap

\section{VD of CPI}

(i) Indonesia

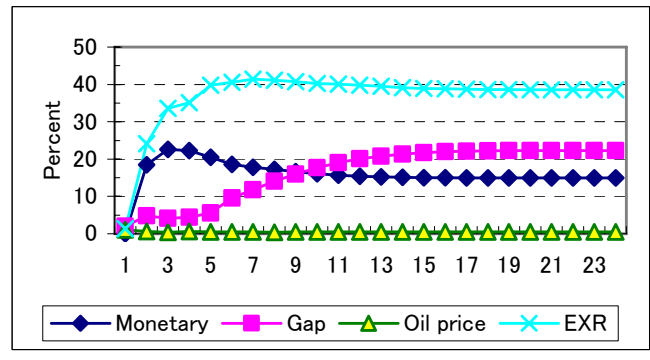

(ii) Korea

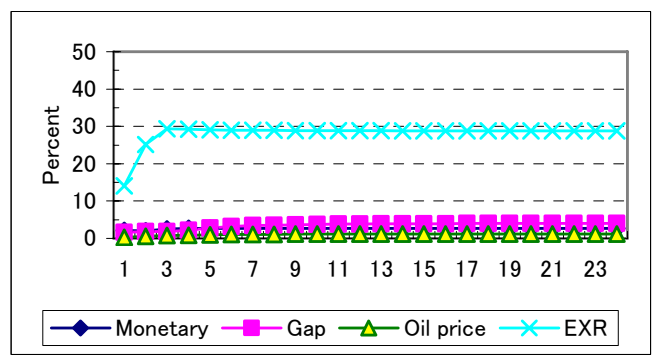

(iii) Thailand

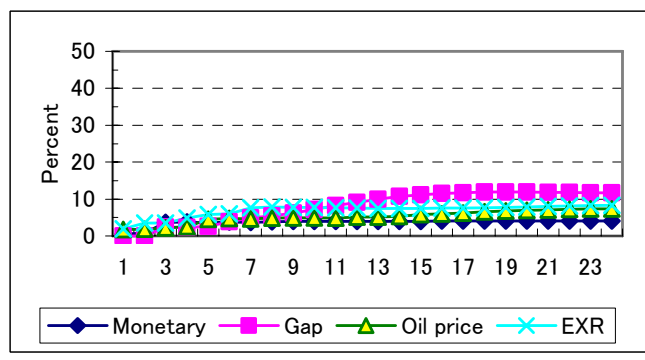

(iv) Singapore

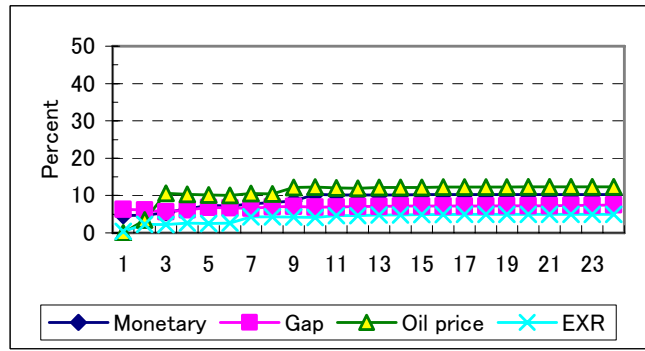

(v) Malaysia

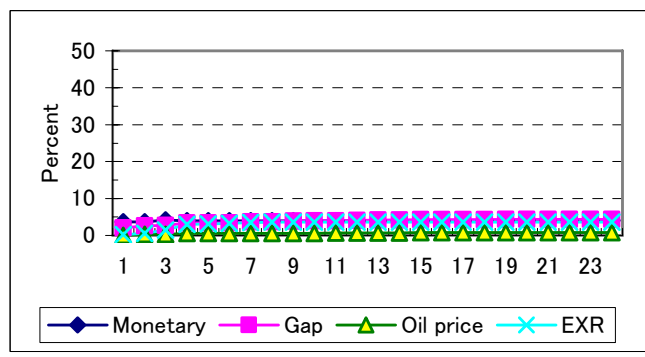

2. VD of Output Gap

(i) Indonesia

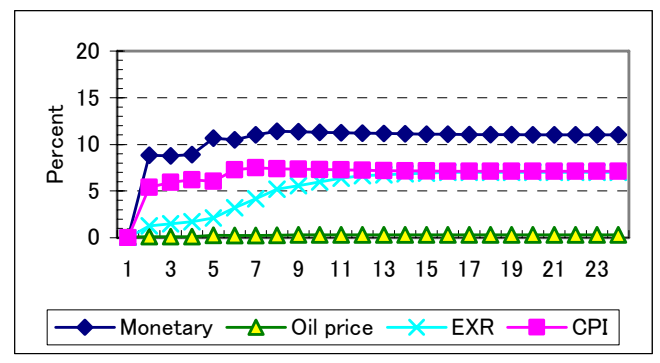

(ii) Korea

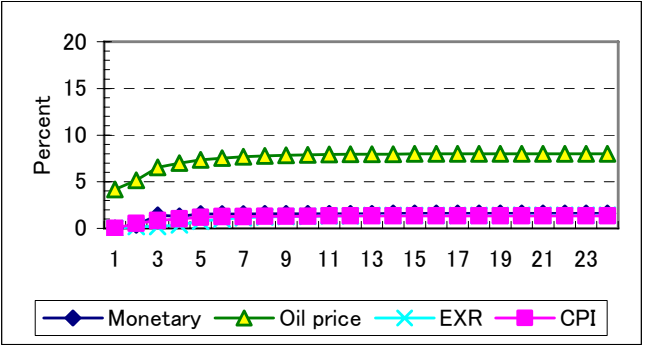

(iii) Thailand

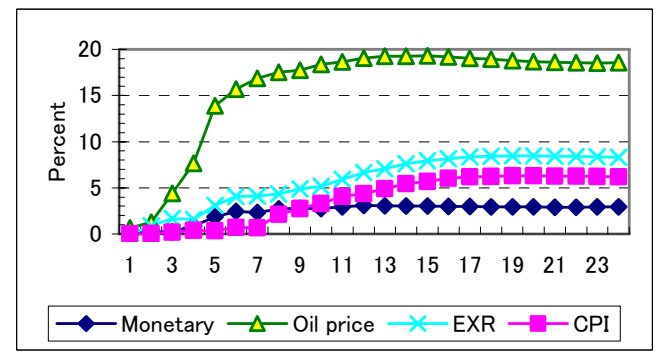

(iv) Singapore

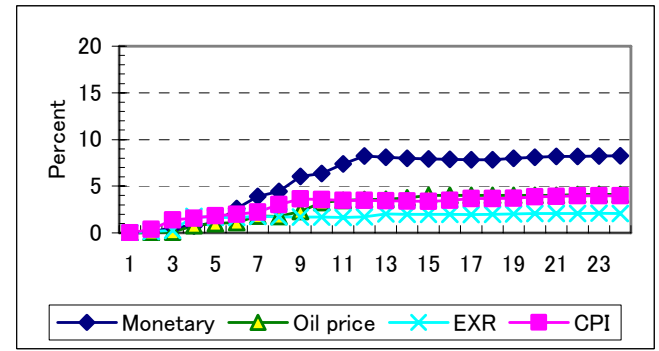

(v) Malaysia

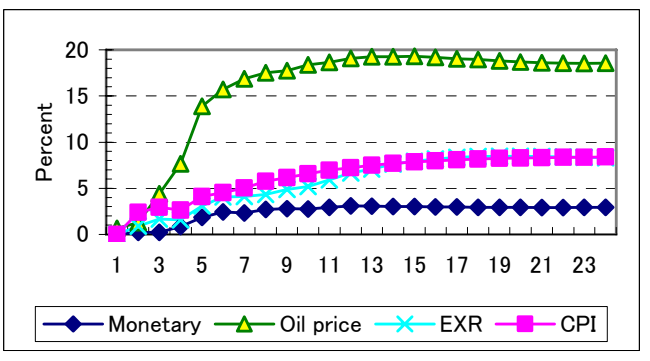


Figure 9. Variance Decomposition (VD) of CPI and Output Gap (cont'd)

Notes: The results of Variance Decomposition tests using the baseline model are presented. The vertical axis shows the percentage contribution of shocks to the variance of the $k$-step ahead forecast errors of respective variables. The horizontal axis represents the time horizon (1 through 24 months). "Monetary" = monetary policy shock; "Gap” = demand (output gap) shock; "Oil price" = oil price shock; "EXR" = exchange rate shock; and "CPI" = CPI shock. 
Figure 10. Impulse Response of CPI to exchange rate and monetary policy shocks with Different Sample Period and VAR Orderings

\section{Indonesia}

Case 1: Baseline Model with the sub-sample from July 1997 to August 2005 (i) EXR shock $==>$ CPI

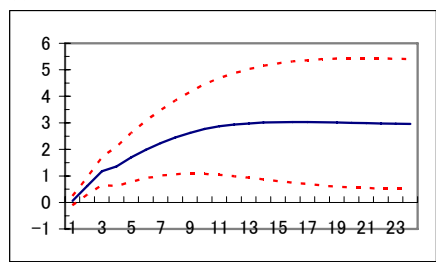

(ii) Monetary policy shock $==>$ CPI

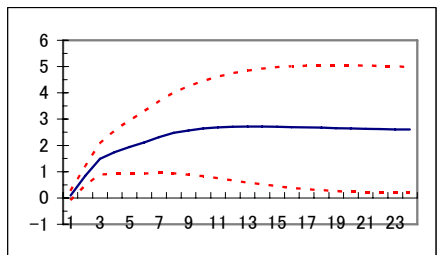

\section{Korea}

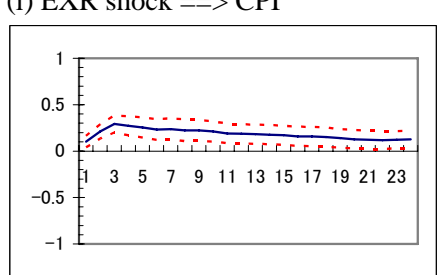

(ii) Monetary policy shock ==> CPI

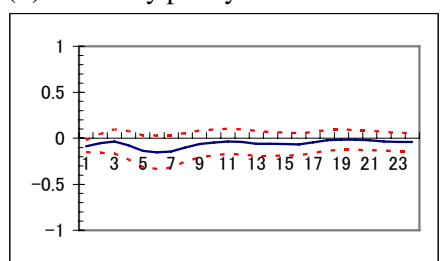

\section{Thailand}

(i) EXR shock ==> CPI

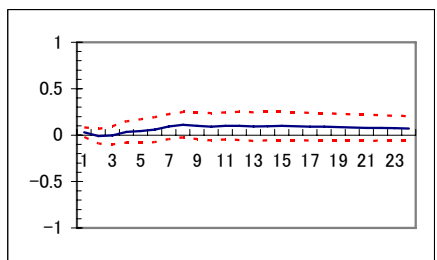

(ii) Monetary policy shock ==> CPI

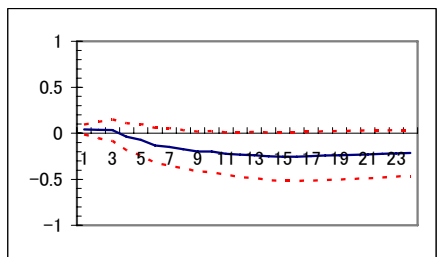

Case 2: Alternative Model 1 with the sub-sample from July 1997 to Auqust 2005

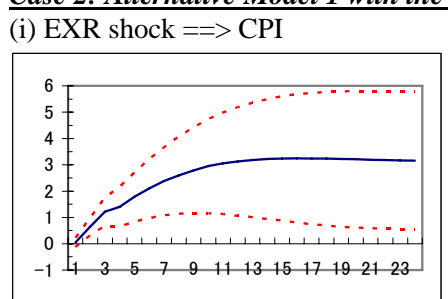

(ii) Monetary policy shock ==> CPI

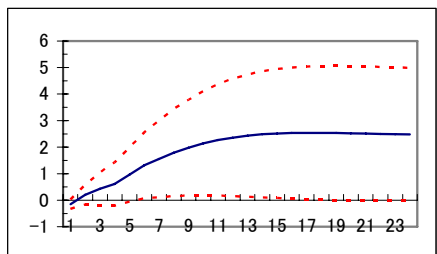

(i) EXR shock $==>$ CPI

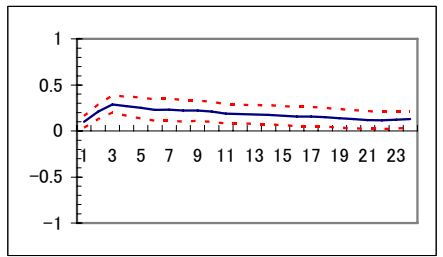

(ii) Monetary policy shock ==> CPI

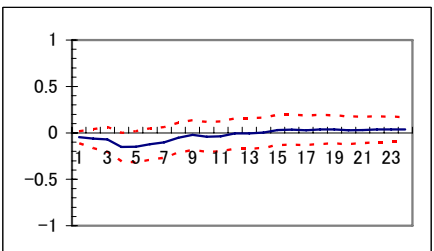

(i) EXR shock ==> CPI

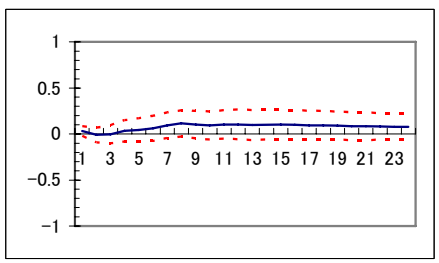

(ii) Monetary policy shock ==> CPI

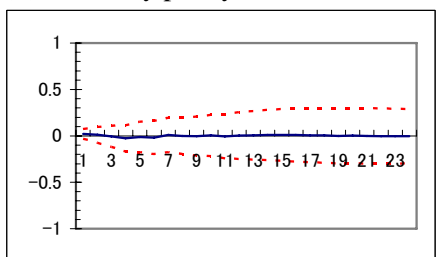

Case 3: Alternative Model 2 with the sub-sample from July 1997 to Auqust 2005

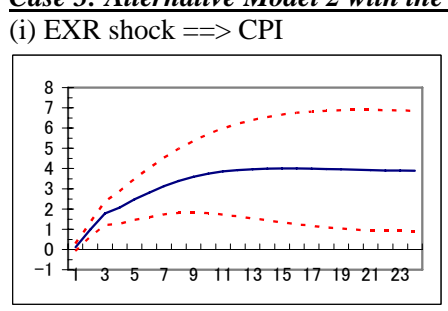

(ii) Monetary policy shock ==> CPI

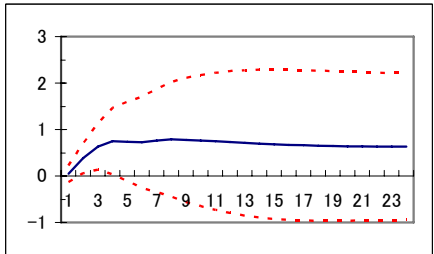

(i) EXR shock $==>$ CPI

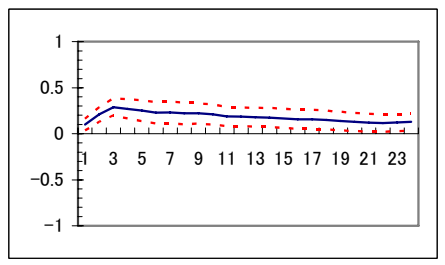

(ii) Monetary policy shock ==> CPI

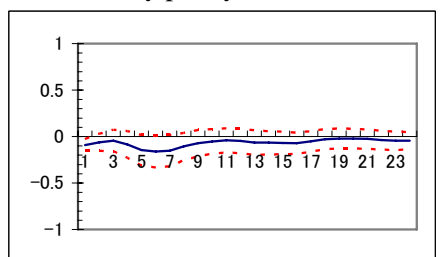

(i) EXR shock ==> CPI

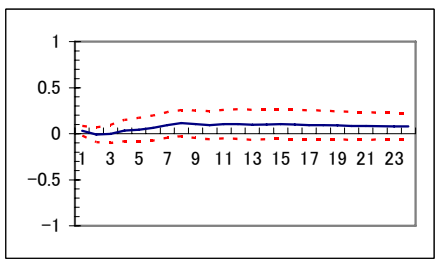

(ii) Monetary policy shock ==> CPI

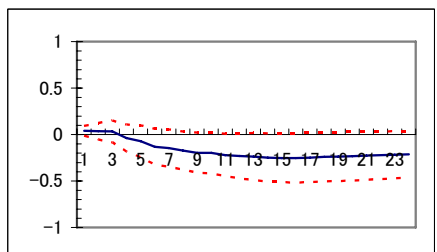


Figure 10. Impulse Response of CPI to exchange rate and monetary policy shocks with

\section{Different Sample Period and VAR Orderings (cont’d)}

\section{Singapore}

5. Malaysia

Case 1: Baseline Model with the sub-sample from July 1997 to Auqust 2005

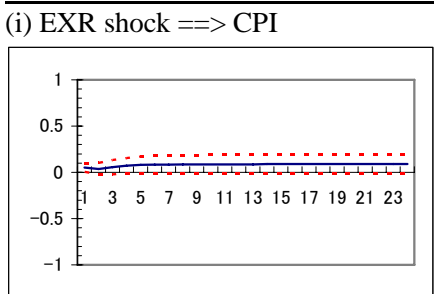

(ii) Monetary policy shock ==> CPI

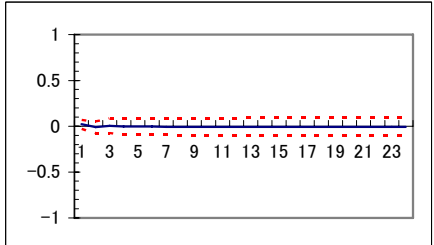

(i) EXR shock $==>$ CPI

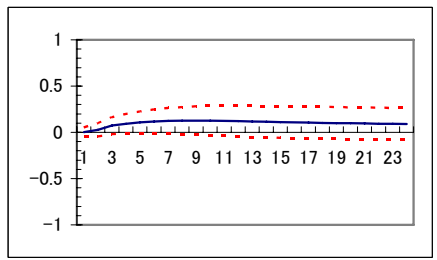

(ii) Monetary policy shock $==>$ CPI

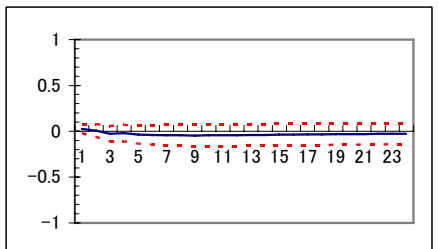

Case 2: Alternative Model 1 with the sub-sample from July 1997 to August 2005

(i) EXR shock $==>$ CPI

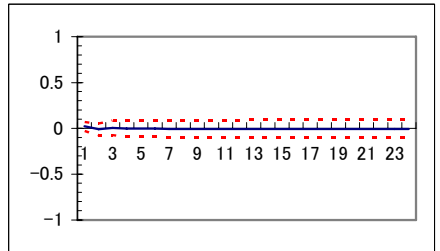

(ii) Monetary policy shock ==> CPI

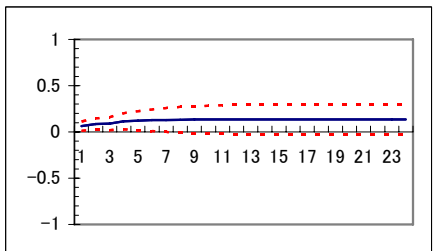

(i) EXR shock ==> CPI

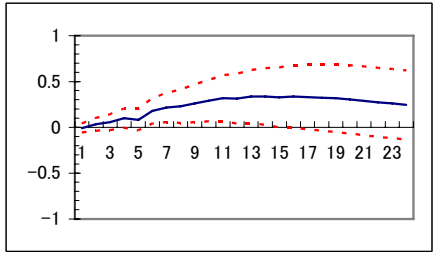

(ii) Monetary policy shock ==> CPI

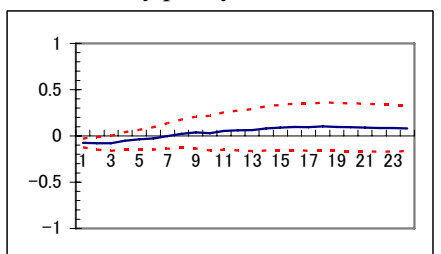

Case 3: Alternative Model 2 with the sub-sample from July 1997 to Auqust 2005

(i) EXR shock $==>$ CPI

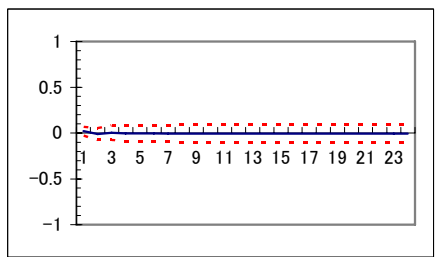

(ii) Monetary policy shock ==> CPI

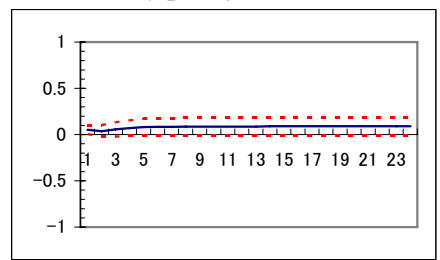

(i) EXR shock ==> CPI

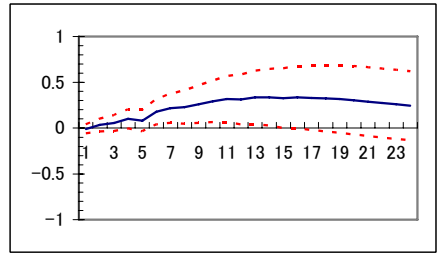

(ii) Monetary policy shock ==> CPI

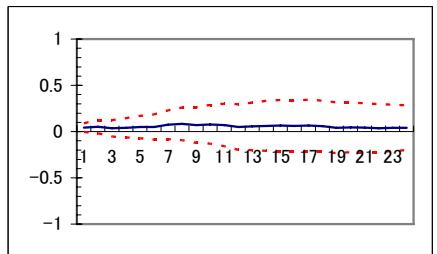


Figure 10. Impulse Response of CPI to exchange rate and monetary policy shocks with Different Sample Period and VAR Orderings (cont’d)

Notes: The response of CPI to the exchange rate (EXR) shock and the monetary policy shock using the three different models are reported.

The baseline model: $x_{t}=\left(\Delta o i l_{t}, \operatorname{gap}_{t}, \Delta m_{t}, \Delta e f e x r_{t}, \Delta p_{t}\right)^{\prime}$.

The alternative model 1: $x_{t}=\left(\Delta o i l_{t}, \Delta m_{t}, \Delta e f e x r_{t}, \operatorname{gap}_{t}, \Delta p_{t}\right)^{\prime}$.

The alternative model 2: $x_{t}=\left(\Delta \operatorname{oil}_{t}, \operatorname{gap}_{t}, \Delta e f e x r_{t}, \Delta m_{t}, \Delta p_{t}\right)^{\prime}$. 